Etnográfica

Revista do Centro em Rede de Investigação em

Antropologia

vol. 11 (2) | 2007

Vol. 11 (2)

\title{
Um museu debaixo de água: o caso da Luz
}

A museum under water: the case of the village of Luz

\section{Clara Saraiva}

\section{Q OpenEdition}

\section{Journals}

\section{Edição electrónica}

URL: https://journals.openedition.org/etnografica/2013

DOI: 10.4000/etnografica.2013

ISSN: 2182-2891

\section{Editora}

Centro em Rede de Investigação em Antropologia

\section{Edição impressa}

Data de publição: 1 novembro 2007

Paginação: 441-470

ISBN: 0873-6561; E-ISBN 2182-2891

ISSN: 0873-6561

\section{Refêrencia eletrónica}

Clara Saraiva, «Um museu debaixo de água: o caso da LuZ», Etnográfica [Online], vol. 11 (2)| 2007, posto online no dia 27 setembro 2012, consultado o 10 fevereiro 2022. URL: http://

journals.openedition.org/etnografica/2013 ; DOI: https://doi.org/10.4000/etnografica.2013

\section{(@) $(1) \Theta$}

Etnográfica is licensed under a Creative Commons Attribution-NonCommercial 4.0 International License. 


\section{Um museu debaixo de água: o caso da Luz}

\section{Clara Saraiva}

O Museu da Luz foi inaugurado no ano de 2003, no âmbito do realojamento da aldeia da Luz, submergida devido à construção da barragem de Alqueva, no Sul de Portugal. A sua criação foi solicitada desde o início pela comunidade. Este processo incluiu igualmente a trasladação integral do antigo cemitério para uma nova necrópole e a reconstrução da velha igreja matriz do séc. xv, edificações de grande carga simbólica e com as quais o novo museu estabeleceu uma forte relação. Este texto pretende dar conta do que é este museu e de algumas das vicissitudes que marcaram o complexo processo de trasladação da aldeia e de criação deste equipamento na nova Luz.

PALAVRAS-CHAVE: barragem de Alqueva, Sul de Portugal, processo de realojamento, Museu da Luz, etnografia, musealização.

À memória da Maria João George. Sem ela o Museu da Luz não existiria.

Para o Benjamim, que está presente em cada linha escrita.

\section{AS DUAS ALDEIAS}

No Sul de Portugal, uma zona com clima seco e escassez de água, a ideia da construção de uma grande barragem surgiu inicialmente nos anos 50, durante o regime salazarista, mas só se concretizou nos anos 90, duas décadas após a revolução do 25 de Abril de 1974. A construção desta unidade implicou a trasladação da aldeia da Luz, que, por estar abaixo da quota 152, seria totalmente submergida pelo grande lago. Situada no concelho de Mourão, distrito de Évora, a Luz era uma aldeia pacata, ${ }^{1}$ pouca movimentada, já que a estrada que a ela conduzia terminava num cul de sac que apenas dava acesso ao castelo da Lousa, construção romana de reconhecido valor patrimonial e arqueológico. Desde o início do projecto que a população desta aldeia viveu sob a ameaça da 
sua deslocação; no entanto, com a morosidade do processo, que se arrastou ao longo de décadas com avanços e recuos, passou a pensar-se na barragem como algo que nunca chegaria a concretizar-se (Saraiva 2003a: 35).

Como tal, apenas quando, em Fevereiro de 2002, as comportas são encerradas e se inicia o enchimento da barragem, com a nova aldeia já praticamente pronta, os luzenses se deram efectivamente conta de que a mudança era inevitável. Entre Setembro de 2002 e Março de 2003 a aldeia foi inteiramente trasladada para um outro local, construído de propósito para esse efeito a cerca de $2 \mathrm{~km}$ da povoação original, respeitando o desejo das pessoas, que sempre tinham recusado uma indemnização pecuniária, preferindo receber "casa por casa e terra por terra", expressando assim a vontade de se manterem unidas enquanto comunidade. ${ }^{2}$

Todo o processo de decisões relativas ao planeamento e construção da nova aldeia foi extremamente complexo e doloroso. Sentindo-se simultaneamente vítimas e heróis, pelo facto de se terem sacrificado pelo bem do país, à medida que o tempo foi passando os luzenses passaram a reivindicadores. A edificação das novas moradias despoletou um processo de imolação social, em que se disputavam áreas de cada divisão da casa e que criou invejas e cisões no seio da comunidade. Em 1995 havia sido criada a EDIA (Empresa de Desenvolvimento e Infra-Estruturas de Alqueva), uma empresa privada de capitais públicos, que passou a dirigir todo o projecto, quer de edificação da barragem propriamente dita, quer da nova aldeia. A partir daí, a EDIA consubstancializou-se como o inimigo, a entidade responsável pela desgraça que caiu sobre a Luz.

Desde os primórdios do processo que, para além da reivindicação da construção de uma nova aldeia, os luzenses pugnaram pela construção de um museu, pensado como depósito de memória colectiva e como um espaço que permitisse salvaguardar a lembrança da velha aldeia e dos seus víveres. Um inquérito dos anos 80 revela essa intenção, que foi aceite pela EDIA logo desde as primeiras conversações com a população com vista ao planeamento do que iria ser a aldeia a criar. O Museu da Luz foi inaugurado em Novembro de 2003, um ano após a inauguração oficial da nova aldeia.

\section{LUGAR E ESPAÇO ${ }^{3}$}

A ideia de construção de um museu levantava o problema da sua inserção na paisagem urbana da nova Luz. Desde o começo que se pensou que o museu, enquanto depósito de memória e elemento catalisador de ajuda à inserção da população no novo aldeamento, deveria estar intimamente relacionado com o

2 Ao contrário do que se passou em Portugal com Vilarinho da Furna, ou com casos similares noutros países (ver Latz 1979; Novaes 1973; Reymond 1992; Valcelli 2002).

3 Agradeço ao arquitecto Pedro Pacheco a ajuda e a cedência de textos, fotografias e desenhos. 


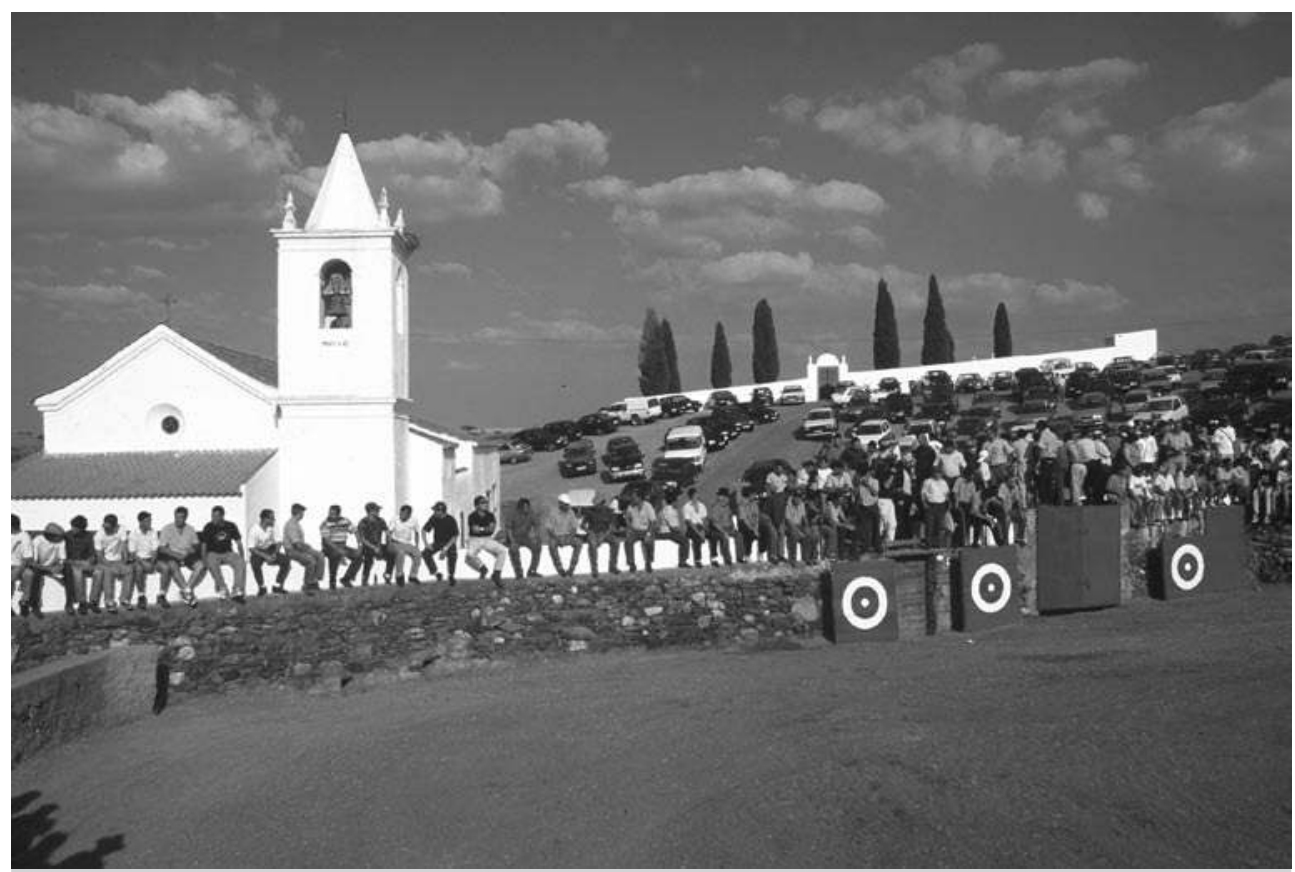

Figura I - Igreja matriz, cemitério e praça de touros em dia de festa.

espaço sintetizador e de referência original da Luz, espaço esse que abarcava o cemitério e o santuário em honra da santa padroeira, ligado à lenda de fundação do povoado, segundo a qual a Nossa Senhora da Luz teria aparecido a um pastor no local onde posteriormente se fixou o templo.

Este conjunto distava cerca de $1 \mathrm{~km}$ do núcleo populacional e integrava, além do cemitério e da igreja matriz, do século XV (com posteriores acrescentos, visíveis nas influências góticas dos portais e capitéis e nas características renascentistas da capela baptismal), a praça de touros: um conjunto que simbolicamente unia as esferas da morte e da festa, do sagrado e do profano. Todo este conjunto, encabeçado pelo cemitério e pela igreja, teve de ser igualmente transferido para o novo aglomerado, já que o lugar onde se encontravam iria também ser submergido pelas águas. Denominado pela EDIA como "parte monumental e histórica” da Luz, foi objecto de um projecto arquitectónico e paisagístico específico; tendo-se decidido que este espaço seria definido pelo novo elemento a criar, o museu, e que a praça de touros seria mudada para a zona reservada aos espaços lúdicos na nova aldeia, ${ }^{4}$ coube à equipa projectista pensar o modo de articular e implantar estes três edifícios numa nova realidade paisagística, que passaria a estar na margem de um imenso lago.

4 Espaço situado no lado diametralmente oposto da aldeia, junto ao pavilhão gimnodesportivo e às escolas. 
A proposta dos arquitectos responsáveis por esta parte do projecto empenhou-se em guardar a referência ao antigo espaço igreja-cemitério, visto também como estruturante da nova topografia do conjunto e deste seu novo elemento, o museu. A mudança do cemitério acarretava o melindroso problema da trasladação integral da comunidade dos antepassados. A ideia da mudança destes espaços históricos e sua subsequente destruição fez com que a equipa considerasse a deslocação da Luz como um acto de substituição, "uma dupla e simultânea acção de fundação e destruição" (Pacheco e Clément 2003: 107), um duplo processo de transformação da paisagem, em que a antiga aldeia permaneceria como um "embrião conceptual, pensando uma primeira natureza construída durante séculos de apropriação do território e uma segunda pensada e elaborada como uma nova identidade", tal como referem no plano inicial: "A fundação do lugar constituído pela igreja $\mathrm{N} .{ }^{\mathrm{a}} \mathrm{Sr}^{\mathrm{a}}$ da Luz, o cemitério trasladado e o museu dedicado aos territórios da Luz, procura absorver numa nova situação topográfica e geográfica as analogias ao lugar da antiga Igreja da N. ${ }^{a}$ Sr. ${ }^{a}$ da Luz - a Igreja e o cemitério como fortes elementos identitários, pré-existências únicas e o museu como elemento estruturante do novo lugar, dotado de carga representativa da substituição" (Pacheco e Clément 2006: 1). ${ }^{5}$ O processo de desmontagem da aldeia da Luz, que traria à superfície indícios vários, de carácter arqueológico, antropológico, histórico e arquitectónico, que abrangiam um vasto território circundante, reforçava a aproximação simbólica à terra mãe fundadora.

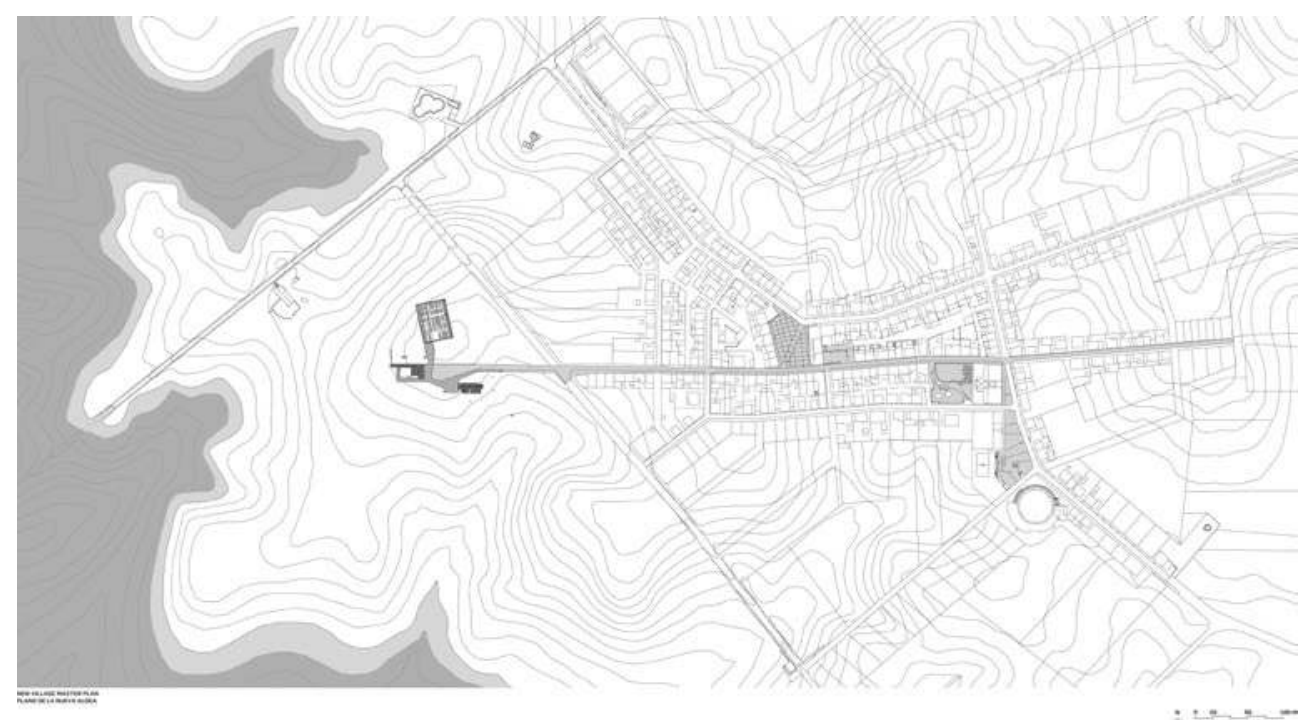

Figura 2 - Planta de nova aldeia com espaço igreja/museu/cemitério perto da água. 


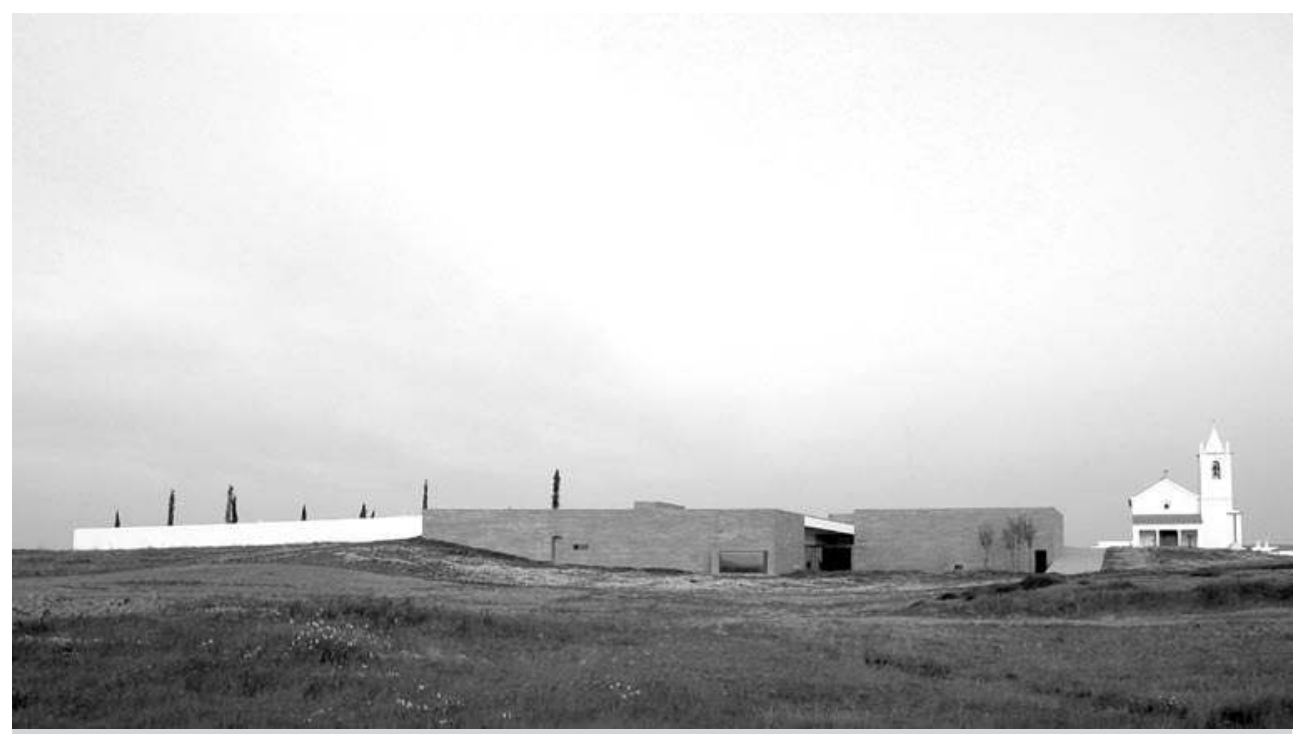

Figura 3 - Cemitério, museu e igreja.

Esta noção de elemento fundador é também perceptível na forma como a equipa projectista optou por um edifício semi-enterrado, devolvido assim ao solo xistoso original, perceptível apenas ao centro, posicionado entre a igreja reconstruída e o cemitério trasladado, como uma espécie de espaço mediador entre o passado sintetizado pela velha igreja matriz e todos os rituais lá realizados ao longo dos séculos, e o cemitério, detentor por excelência da memória colectiva local: "O museu redesenha a topografia do sítio numa relação telúrica com a paisagem, reflectindo a condição de edifício como marca identitária, onde os percursos, os muros e a luz evidenciam elementos da própria cultura da construção do território" (Pacheco e Clément 2006: 1).

Situando este conjunto tripartido na continuidade da estrutura urbana da aldeia, mas um pouco afastado dela, a aproximação faz-se gradualmente, quando se caminha do centro do povoado até aqui. A igreja, orientada este/ oeste, o muro poente do cemitério e a parte visível do museu definem um espaço de intervalo enquadrado em todas as direcções pela paisagem.

A utilização da policromia dos materiais complementa a definição simbólica dos espaços e a função do museu, como espaço entre a igreja e o cemitério, pensado sobretudo como elemento da paisagem e não como mais uma construção: o adro da igreja com um tapete de pedra branca de quartzo no pavimento, o muro escuro do museu, em xisto, e à direita, de novo a presença do branco, no muro caiado do cemitério. $\mathrm{O}$ acesso ao museu é feito por uma rampa, da qual se avista a albufeira que rodeia este espaço e que termina num pequeno jardim, excerto da paisagem local, perpetuando assim a relação com os dois elementos fundamentais: a terra original, e a água, agente da transformação. 


\section{MATERIAIS}

No seio de um processo que implicou uma alteração radical nas vivências da população e a destruição das suas raízes culturais e territoriais mais fundas, o museu surgiu como um potencial pólo unificador e identitário essencial, capaz de dinamizar e centralizar dinâmicas culturais e lúdicas que ajudassem os luzenses a ultrapassar o trauma decorrente da violação de privacidades e vidas que o realojamento acarretou, assim como na sua adaptação ao novo espaço. Foi esta concepção de museu que desde logo se tentou implementar e se transpôs para a própria entidade material, o edifício em si, que se quis espelho não só dessas raízes paisagísticas e culturais da região, mas também símbolo das vicissitudes por que a aldeia iria passar.

Como tal, o material escolhido foi o xisto de cores pastel - com uma paleta de tonalidades de verde seco, castanho claro, cinzento, amarelo e rosa - da região, extraído em pedreiras da zona; nas palavras do arquitecto, a escolha do xisto "aproxima-o mais à terra, ao solo xistoso e à ideia de fundação" (Pacheco e Clément 2006: 1). O xisto encontra-se abundantemente na área, sendo visível quer como parte da paisagem natural, quer implantado na paisagem construída, como nos muros que dividiam propriedades e definiam caminhos na antiga Luz.

O castelo da Lousa, ruína de uma vila romana do séc. I a.C., instalada na margem esquerda do rio Guadiana, testemunho de uma das primeiras ocupações sedentárias humanas neste território, foi, no seu desenho e materialidade seculares, o mote inspirador. Condenada também ela a desaparecer sob as águas da albufeira, esta construção revelava uma planta geométrica constituída por estratos horizontais de xisto sobre um afloramento também ele xistoso; as várias camadas deste material sobrepostas davam a este testemunho uma estética e beleza muito própria e emblemática da região, que se transpôs para o novo edifício do museu.

Além do xisto, os planos para o museu aproveitaram o duplo significado do topónimo "Luz": como nome da aldeia sacrificada e como elemento natural, doravante associado ao outro novo elemento que passaria a circundar o museu, as águas da albufeira. O edifício aliou o xisto à madeira e a paredes brancas, conjugadas com várias chaminés de luz que permitem a passagem da luminosidade natural para dentro em vários momentos e a presença da água, evocada através do pátio (impluviu, sala de água) interior (Pacheco et al. 1998: 12).

\section{MUSEU E LÓGICA ESPACIAL}

À altura do início do estudo arquitectónico para a construção do museu (1998) não existia nem programa museológico nem espólio constituído. A organização dos espaços dentro do museu foi arquitectada sob a égide da adaptabilidade: 
átrio, espaço polivalente e sala de exposições temporárias são todos eles polivalentes, permitindo uma enorme flexibilidade de usos pela utilização/fechamento de janelas que trazem a luz natural exterior para dentro do edifício, e de divisórias móveis que fecham ou abrem espaços consoante a utilização que se pretende. As várias chaminés de luz espalhadas pelas salas permitem a penetração de luminosidade natural, que pode igualmente ser vedada através do fechamento dos alçapões.

O museu foi pensado, nas palavras do museólogo Benjamim Pereira, "como um agente activo e participativo, o interventor qualificado no diálogo ou debate desse momentoso processo, constituindo-se como um espaço privilegiado de reencontro com o passado comum, num equipamento cultural que participe no desenvolvimento da comunidade local e que, através de um processo interactivo, pode projectar reflexões e experiências de valorização de práticas decorrentes do novo contexto emergente" (Pereira

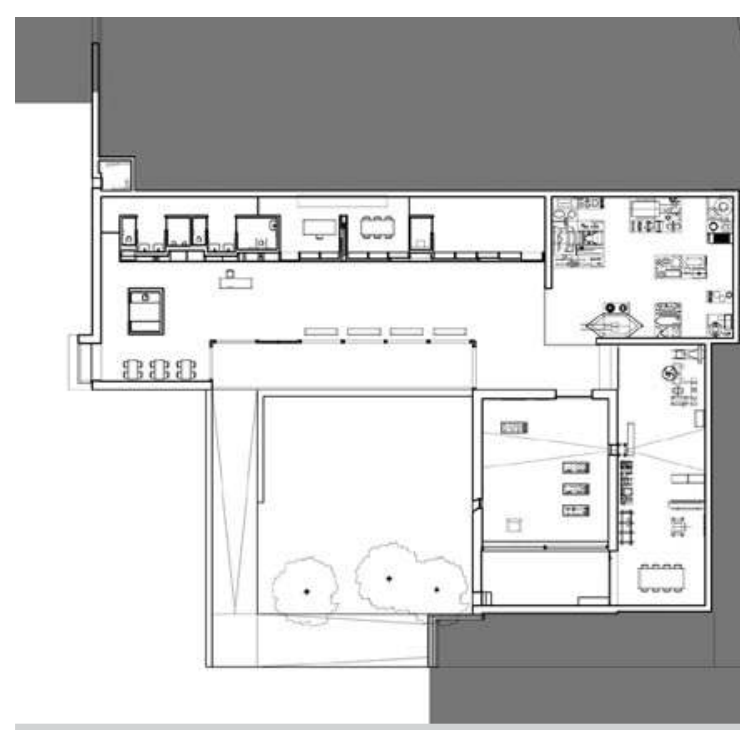

Figura 4 - Planta das salas. 2003: 49).

Com o decorrer do processo, foi possível o diálogo entre os arquitectos e o museólogo, tendo-se chegado a um projecto arquitectónico que se coadunava com as ideias do segundo sobre o que iria inicialmente ser exposto e o que poderia ser o futuro das várias salas. O projecto expositivo baseou-se na ideia da conjunção entre exposições temporárias de longa duração e exposições temporárias de curta duração. Presentemente, continua patente ao público o conjunto de exposições temporárias inaugurais directamente relacionadas com o processo de submersão do território da Luz.

Foram ab initio pensadas três salas. A Sala da Luz, como figura central do museu, deveria remeter para uma síntese da memória da antiga aldeia, recorrendo a testemunhos materiais, mas também usando o próprio desenho e estrutura da sala como símbolo; daí resultou um espaço inteiramente pintado de branco (pavimento, paredes e tecto), de aspecto luminoso e etéreo, onde, através da clarabóia da cobertura invisível, se ilumina o perímetro do tecto suspenso. Esta entrada de luz é reforçada pela abertura para um pátio de luz interior, onde se plantou um loendro, remetendo todos estes elementos - pátio, loendro, e jogos de dualidade entre interior e exterior, sombra e luz - para a 


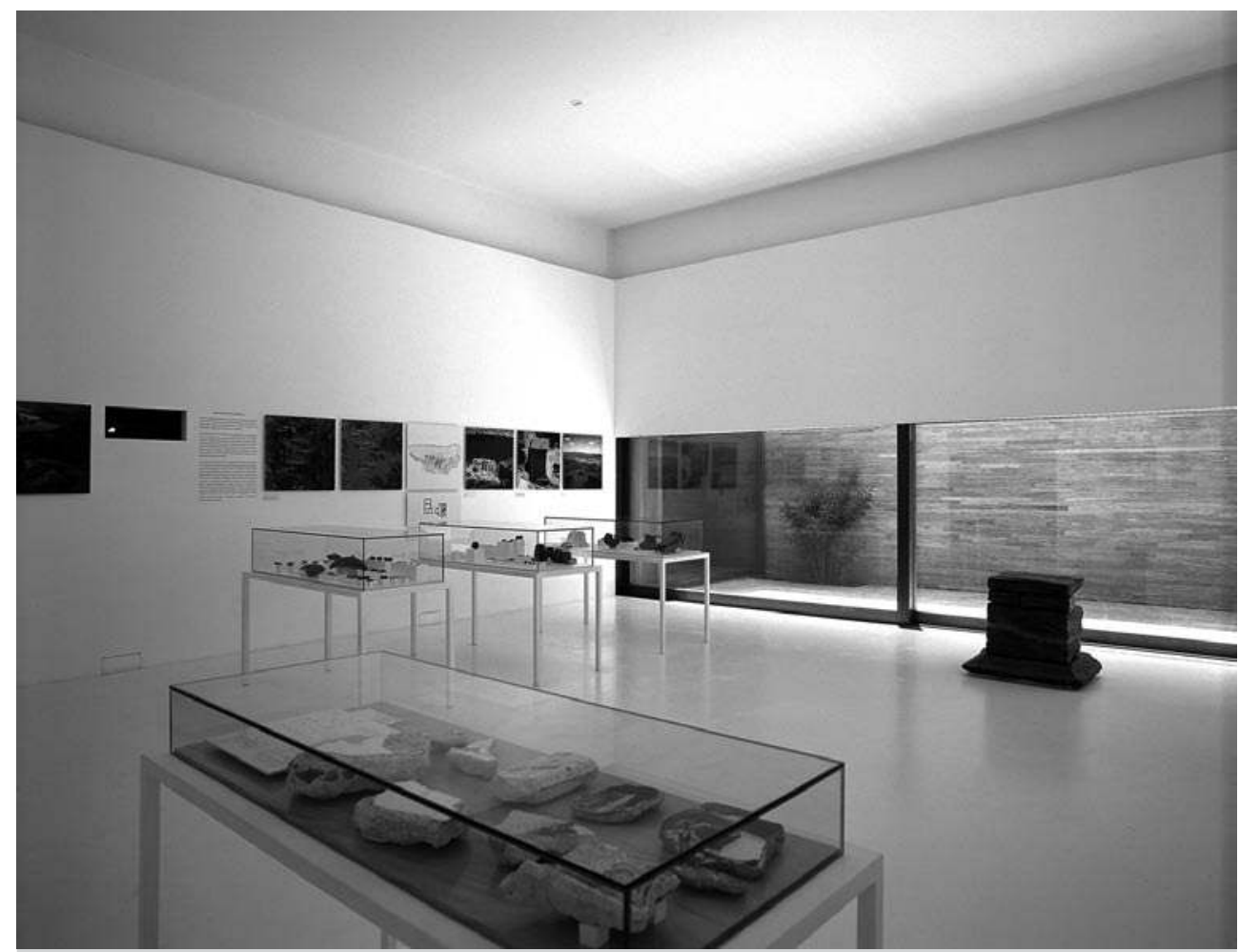

Figura 5 - Sala da Luz.

arquitectura e paisagem da região. Do interior da sala retoma-se a relação com a paisagem através de uma pequena janela da qual se avista o antigo espaço da velha aldeia, sintetizado no único elemento não submergido, o Monte dos Pinheiros. Os testemunhos baseados em elementos arqueológicos, documentos históricos e imagens projectadas da paisagem circundante, submergida pela albufeira, são assim complementados com a visualização do local da implantação da antiga aldeia da Luz e a evocação da "luz" pela luminosidade natural do espaço alvo, por forma a completarem o quadro simbólico de referência à aldeia desaparecida.

A Sala da Memória foi pensada como um espaço-depósito onde se pudesse constituir e organizar materiais para futuras exposições temporárias, mas igualmente como um local de pesquisa e diálogo, que integrasse acervos documentais e de imagem. Também em termos expositivos esta sala remete para a memória de tempos, ocupações e acontecimentos que marcaram a vida dos luzenses, apresentando três núcleos expositivos temáticos - a oficina do ferreiro, a oficina do abegão e as técnicas de construção em barro. Em cada um destes núcleos, os objectos (antes pertença dos mestres da Luz que os doaram ao museu), permitem reviver e entender o que foram três das actividades essenciais das gentes 


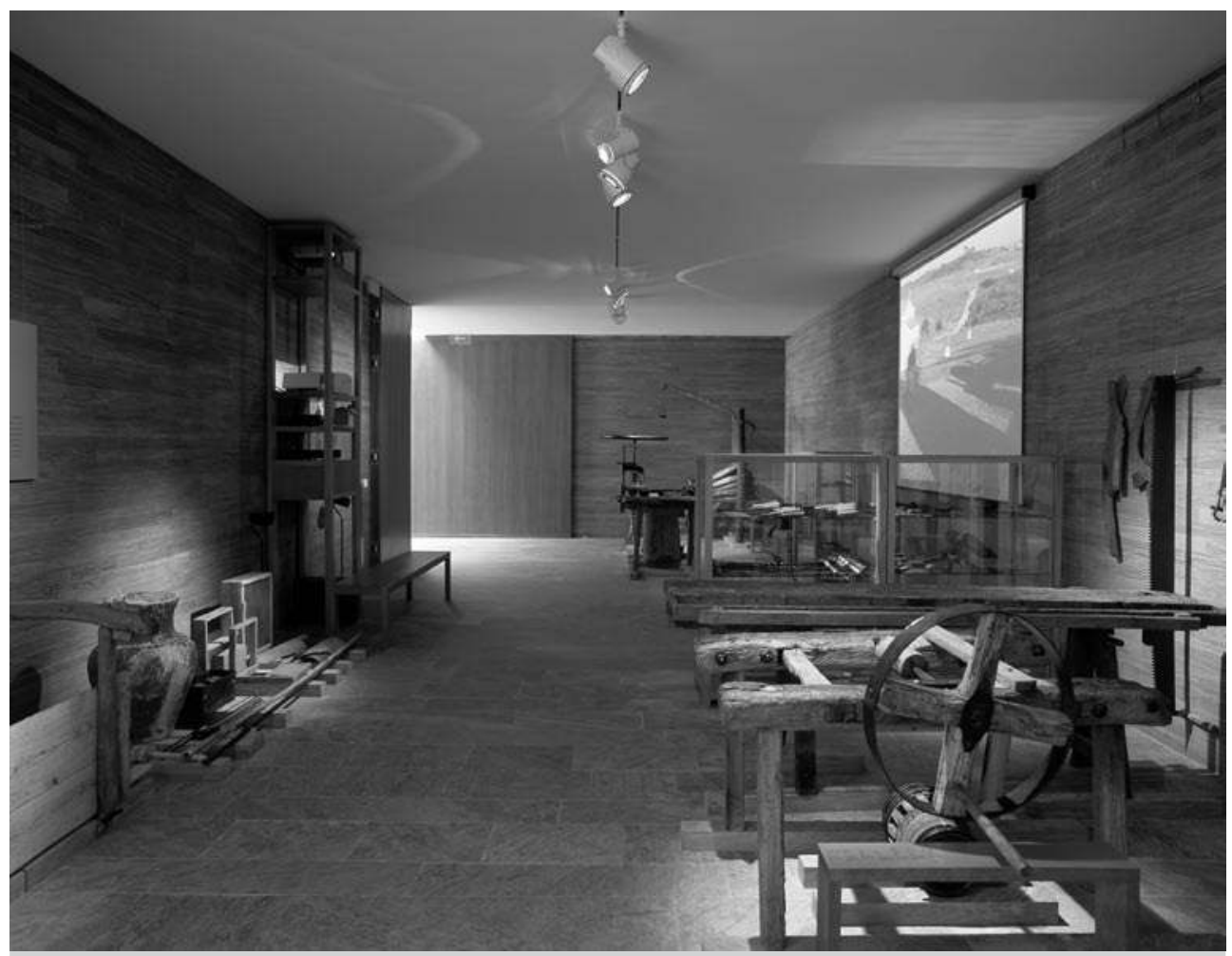

Figura 6 - Sala da Memória.

da Luz ao longo de séculos - o abegão e o ferreiro (que trabalhavam em conjunção no fabrico do equipamento material essencial para o funcionamento das lavouras, nomeadamente carros de parelha e de varais, cangas, arados, grades, trilhos, enxadas, alviões, foices, machados, ancinhos, forcados, etc.), e os sistemas e materiais de construção em terra. Nestes, destacam-se nomeadamente a taipa, em que a terra é amassada com água e socada entre dois taipais colocados no limite externo das paredes, e as baldosas, tijolo e telha caleira, que eram fabricados nos seis telheiros que existiam na periferia da aldeia.

O recurso à imagem em movimento, através da projecção em contínuo de um excerto fílmico com imagens de momentos importantes da vida nos últimos anos de existência da velha Luz (contendo registos do quotidiano do trabalho nos campos, pastoreio, pesca, celebrações cíclicas e a festa anual em honra da Nossa Senhora da Luz), reforça a ideia de um espaço de memória que se quer não obstante activo e vivo, como salientam as autoras dos registos audiovisuais: "Mais do que um álbum de família colectivo e em movimento, que muitas vezes apenas exige uma atitude passiva e contemplativa, consideramos que a sala da memória deverá ser um espaço dinâmico de interacção e reinvenção, intervindo e afectando a realidade presente e futura (Mourão e 
Alves Costa 2003: 103). Além do filme-síntese que passa continuamente, os registos efectuados ao longo de cinco anos (de 1999 a 2004, sendo o ano de 2002 o ano mais importante desse registo), organizados e arquivados tematicamente, podem ser consultados e visionados num computador presente nesta sala e disponível ao público.

Este espaço é encimado pela presença de uma mesa e cadeiras, um pequeno espaço de convívio que pretende ser uma extensão dos lugares de sociabilidade das aldeias alentejanas, onde se realizam encontros temáticos, lançamentos de livros, etc.

Na Sala de Exposições Temporárias a exibição "A terra - ocaso de uma relação milenar" mostra parte do acervo do museu, representativo de um conjunto de objectos relativos a ofícios tradicionais de apoio à agricultura que sustentavam um modo de vida autárcico e que se mantiveram ao longo de um tempo longo de milénios, tendo desaparecido de cena no último quartel do século XX.

Surgem assim vários núcleos expositivos: o da agricultura, já que ela foi a actividade essencial das gentes da Luz (com relevo para os trabalhos respeitantes às culturas cerealíferas em regime de afolhamento), em que o arado de pau e o trilho, que reteve a forma original dos plostellum dos romanos (Pereira 2003: 51 ), constituem testemunhos desse mundo rural alentejano praticamente desaparecido; o núcleo dos transportes, com um carro de varais recolhido num dos

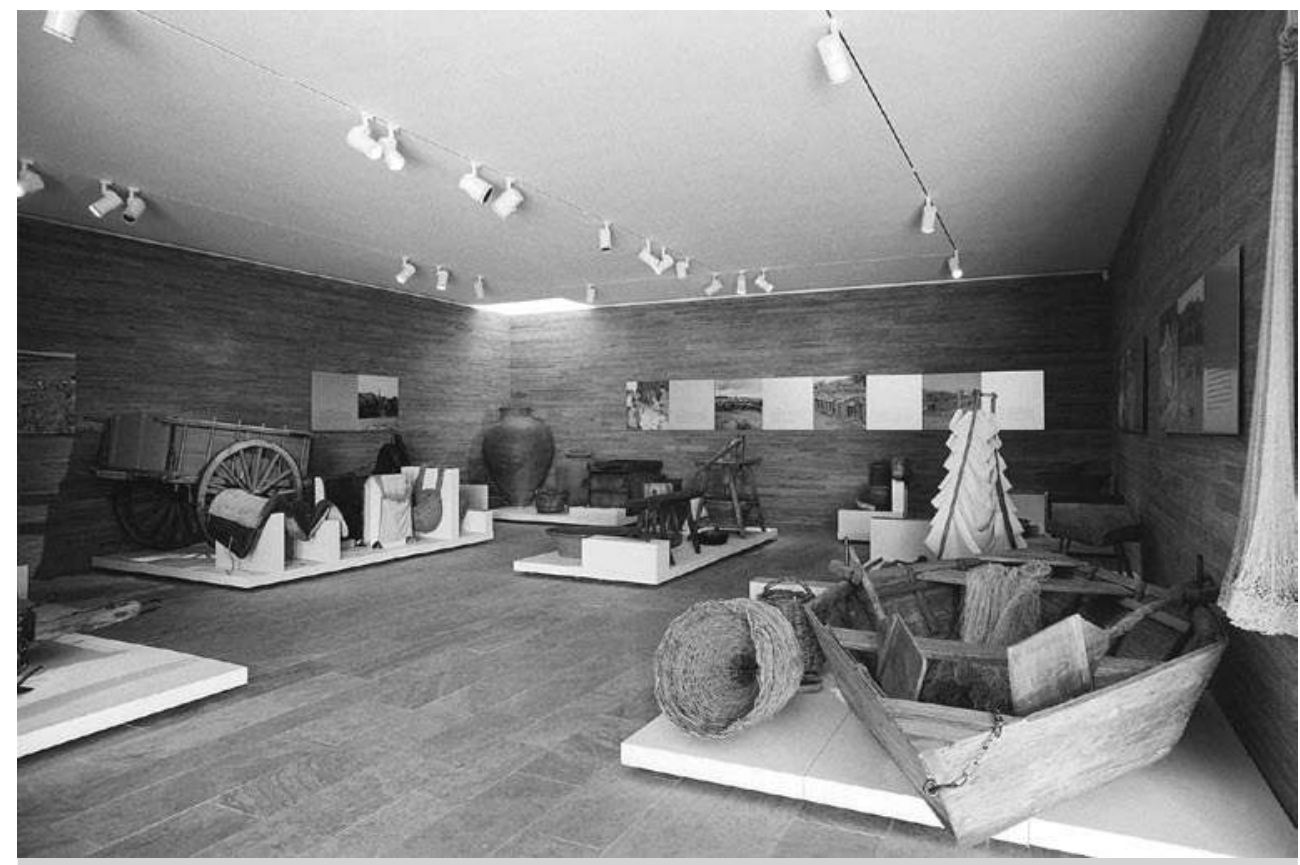

Figura 7 - Sala de Exposições Temporárias. 
montes onde as pessoas da Luz trabalhavam. O pastoreio, ligado à exploração pecuária praticada nos montes circundantes da Luz, encontra-se documentado através de objectos como os chocalhos dos animais e o cajado do pastor, e é completado pelo quadro referente à matança do porco, praticada tradicionalmente por todas as famílias, com o banco da matança, e a máquina (manual) e o alguidar usados no fabrico e preparação dos enchidos de porco. Os conjuntos dedicados ao fabrico do pão (com o cadeirão de amassar e a tábua de tender o pão, entre outros objectos), do vinho (amplamente ilustrado com uma caixa de vinho, inteiramente em madeira, usada para fazer vinho com o ripanço) e do mel (com uma máscara de arame usada para proteger o rosto) mostram as várias actividades artesanais que chegaram aos nossos dias. A pesca foi sempre uma actividade subsidiária, mas importante, praticada amiúde pelos moleiros que viviam junto ao rio: um barco tradicional do Guadiana, de fundo chato, redes de tarrafa, de tresmalho, uma nassa e um cesto de peixe, ambos em verga, dão conta do que foi esta actividade, num rio que agora se transformou em lago.

\section{A CONSTITUIÇÃO DE UMA RESERVA PARA O MUSEU: O MONTE DOS PÁSSAROS}

O Museu da Luz tem um acervo de cerca de 1200 peças, das quais apenas 234 estão expostas. À medida que se foram recolhendo ficou claro que seria necessário um espaço de reservas, já que no edifício original a zona destinada a arrumos é diminuta, nunca tendo sido pensada como zona de reservas. Devido à necessidade premente de criar condições para manter estas peças preservadas e passíveis de serem fruídas pelo público, e ainda permitir a rotatividade de exposições no museu, em 2006 foi aprovado pela EDIA o plano de construção de um espaço de reservas adjacente ao Monte dos Pássaros, da responsabilidade da mesma equipa projectista do museu. ${ }^{6}$

Monte é o nome em geral dado a uma unidade de exploração agrícola no Alentejo, que tradicionalmente recobria variadas formas de acordo com a diversidade das características e exigências dessa unidade. Nos casos de maior vulto compreendia a casa do proprietário ou do rendeiro e instalações para os trabalhadores rurais, permanentes ou eventuais, e para os artífices dos vários mesteres necessários ao funcionamento autárcico da unidade, como abegões e ferreiros, e ainda lojas e cómodos para os gados - cabanais e malhadas de porcos -, armazenamento de alfaias e produtos das colheitas, celeiros, amassaria e forno do pão, rouparias para o fabrico dos queijos, etc. (Pereira 2005).

6 Ver PACHECO, Pedro, e Marie Clément, 2004 Núcleo Etnográfico do Monte dos Pássaros. Estudo Prévio, manuscrito, Lisboa. 
A Luz, como todas as outras aldeias alentejanas, tinha na sua zona circundante inúmeros montes, pertença das famílias mais abastadas de proprietários agrícolas, onde trabalhavam muitos dos habitantes da aldeia. Vários desses montes foram submergidos pelas águas da albufeira. O Monte dos Pássaros, situado ao lado da antiga estrada que conduzia à velha Luz, encontra-se agora na margem do lago, muito perto do local de implantação do novo aldeamento, junto ao espaço ocupado pelo triângulo igreja-museu-cemitério. Se este conjunto, pela sua implantação e inter-relação entre os seus elementos espaciais e arquitectónicos (de que a rampa de acesso, as chaminés de luz do museu, o alpendre e o adro da igreja, o caminho e antecâmara do cemitério são bons exemplos), pretende dar uma certa continuidade ao espaço histórico existente na velha aldeia e evidenciar o seu carácter estruturante numa paisagem ainda em transformação, o Monte dos Pássaros complementa sem dúvida a leitura deste lugar. Representando uma referência do território da Luz, ele é simultaneamente o último monte que se avistava antes da entrada na antiga aldeia e, na nova situação, o último edifício construído na paisagem a poente em direcção à recém-criada albufeira.

Este monte foi, desde os primórdios do processo, comprado pela EDIA, recuperado e utilizado para vários fins durante os anos de construção da aldeia.

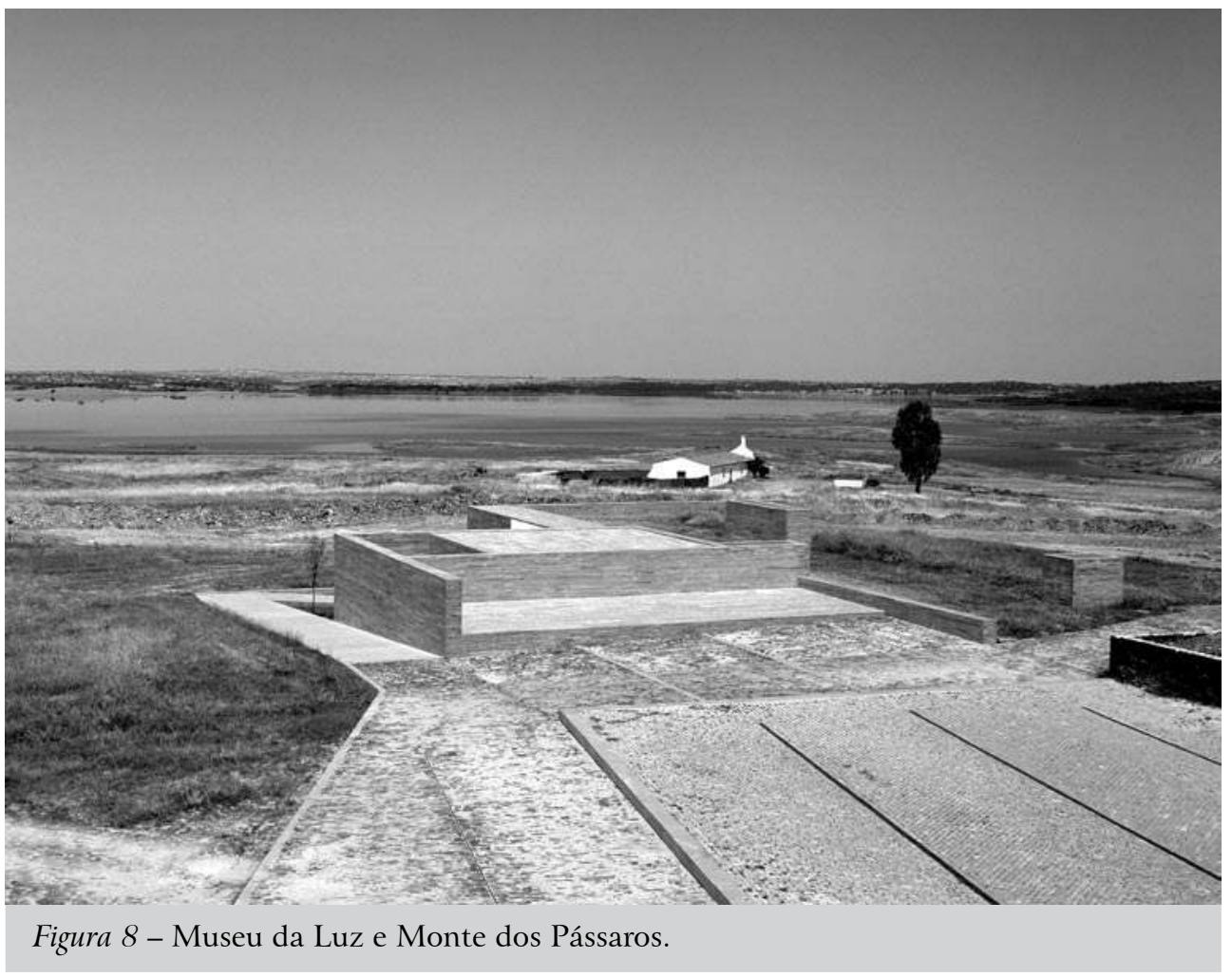


Passou depois, durante o período de preparação para a inauguração do museu, em 2003, a ser uma espécie de reserva provisória e também um espaço de restauro e limpeza dos objectos.

O projecto agora em curso pretende reforçar a ligação do monte ao museu e espaço circundante. A estrada de acesso à antiga aldeia é uma reminiscência de um traçado agora submergido, mas perpetuado na memória local; a intervenção permitirá complementar duas leituras que estabelecem uma ponte entre o passado e o futuro do monte, e a sua correcta integração na nova aldeia, recuperando a sua identidade: "Neste sentido, a reabilitação do Monte dos Pássaros ganha um especial significado na incorporação de memórias associadas à vida dos campos da aldeia, com uma função identitária social importante e imprescindível no processo de adaptação da população ao novo habitat" (Pacheco e Clément 2004: 5). Deste modo, o projecto compreende um restauro mais cuidado dos espaços dentro do antigo edifício, recuperando a cozinha e chaminé, os fornos, assim como as manjedouras nos espaços originalmente ocupados pelos animais. Esta recuperação, aliada à utilização de mobiliário e objectos da Luz, pretende não só dispor de um testemunho da importância dos montes nesta zona, mas também fruir plenamente esse espaço, que se pretende venha a ser utilizado para festas e convívios, introduzindo uma dimensão lúdica e fazendo-o participar dos rituais de festa da aldeia. Seguindo a lógica tradicional do crescimento dos montes, que eram acrescentados sempre que a unidade rural necessitava de maiores áreas de apoio, prevê-se a construção de um novo edifício, integrado no pátio murado do monte, destinado à reserva etnográfica do museu; trata-se de um edifício neutro, semelhante a um armazém que, em termos estéticos, sendo uma estrutura contemporânea, receptora de novos conteúdos resultantes do processo por que a Luz passou, pretende estabelecer um diálogo com a estrutura existente, representante do passado. Concebeu-se assim uma Sala de Reserva, com uma galeria de objectos, onde estes estarão acomodados mas visitáveis pelo público, e uma Sala de Conservação e Restauro.

\section{ENTRE TURBINAS E PESSOAS}

O concurso público para adjudicação da construção da "parte monumental" teve lugar em 1998 e incluía, como vimos, o museu, a igreja matriz e o cemitério. A equipa de arquitectura que ganhou este concurso contou com a colaboração de um museólogo e de uma antropóloga- Benjamim Pereira e eu própria. ${ }^{7}$ Foi deste grupo que saiu a equipa pluridisciplinar que, entre 1999 e 2004, organizou recolhas etnográficas e audiovisuais e organizou os artefactos que

7 A equipa de arquitectos foi constituída e dirigida por Pedro Pacheco e Marie Clément, e compreendia ainda uma historiadora e um arquitecto paisagístico. 
deram origem ao Museu da Luz. Quando começámos a trabalhar com a equipa de arquitectos para o projecto da construção, nos finais de 1998, apercebemo-nos de imediato de que, apesar de a EDIA ter acatado a vontade das pessoas de terem um museu na nova aldeia, não havia nenhum trabalho de preparação, investigação ou recolha de dados ou de materiais destinados a constituir o acervo do futuro equipamento. Estávamos assim na iminência de termos um edifício vazio, sem conteúdos.

Em 1999 apresentámos à EDIA um Projecto de Assistência Técnica para o Museu da Luz. Este documento propunha uma actuação entre Setembro de 1999 e Setembro de 2001, ano em que se previa, nessa altura, a inauguração do museu. Defendia-se a criação de uma equipa multidisciplinar, na sequência do que já tinha acontecido para a elaboração do projecto arquitectónico, integrando as áreas da antropologia, história, museologia e audiovisuais, e a continuação da ligação às equipas de arqueologia que há vários anos trabalhavam no terreno. ${ }^{8}$ Nessa proposta listavam-se uma série de objectivos inerentes às várias áreas de estudo. O pilar básico era a proposta de uma recolha etnográfica consistente, que pudesse funcionar e dar apoio ao projecto museológico: "O Museu, através do Depósito da Memória, da Sala da Luz e dos demais espaços será o local onde se retratará a vida da antiga aldeia e as suas atmosferas e se reflectirá sobre a adaptação à aldeia recém-criada. Para que isto aconteça é necessário empreender-se desde já um apurado trabalho de recolha etnográfica, de modo a que se possa retratar o que era a vida na velha aldeia por oposição (e complementaridade) com a da nova. Só deste modo as gerações futuras se poderão aperceber do que era a realidade da antiga comunidade e compreender as mudanças operadas no seu seio, decorrentes da mudança para outro espaço. Esta pesquisa deverá organizar-se segundo os moldes de uma monografia da velha aldeia da Luz, e contemplar aspectos essenciais do quotidiano das pessoas, tais como a organização social e a estrutura fundiária e familiar; os modos de vida tradicionais, incluindo as actividades no rio e o ciclo agrícola anual; as festas locais e outros momentos de sociabilidade colectiva" (Saraiva 1999: 8).

A pesquisa histórica pretendia aprofundar o conhecimento sobre o espaço monumental e primordial da igreja matriz e cemitério, completando deste modo o trabalho dos arqueólogos. Propunha-se ainda um levantamento fotográfico exaustivo, e uma recolha audiovisual que acompanhasse a pesquisa antropológica; todos os estudos deveriam prolongar-se até depois da instalação da nova aldeia, de modo a dar conta de todo o processo de adaptação a um outro espaço e uma outra vida.

8 Deve-se aqui referir que a arqueologia beneficiou do efeito "Foz Côa" e quando, nos anos 90, o projecto de Alqueva foi retomado, começaram de imediato os estudos arqueológicos. O mesmo não aconteceu com a área da Antropologia e Etnografia, como veremos. 
A proposta, verbalmente aceite pela EDIA, financiadora do projecto, sofreu ao longo dos anos várias vicissitudes; foi necessário renegociar o âmbito dos trabalhos, efectuar cortes drásticos, quer em termos de pesquisa a efectivar quer em termos de orçamento. ${ }^{9}$ Esbarrámos com uma máquina administrativa e burocrática da empresa que privilegiava a construção da barragem e os aspectos técnicos do projecto em detrimento dos aspectos humanos. Se a EDIA tinha aceitado a ideia de museu, a verdade é que também achava que bastava "um edifício onde se pusessem lá dentro umas coisas antigas da aldeia". ${ }^{10}$ Convencer a administração que o projecto de investigação e recolha proposto era necessário e um justo tributo à população da Luz foi uma tarefa morosa e complicada. O Projecto de Assistência Técnica para a Constituição do Museu da Luz, finalmente dividido em duas fases, iniciou-se oficialmente em Setembro de 2001, com uma primeira parte entre Setembro de 2001 e Setembro de 2002, e uma segunda no ano seguinte, em que em princípio a população já estaria a viver na nova aldeia, e se poderiam recolher aspectos relacionados com a adaptação ao novo espaço. ${ }^{11}$ Todo o processo de edificação da barragem, de construção das casas e subsequentemente também do realojamento da população foi sofrendo atrasos sucessivos, e a mudança acabou por ter lugar durante o fim do Verão e Outono de 2002.

Apesar destes constrangimentos, o resultado do relatório de execução da primeira fase do trabalho, entregue à EDIA em Outubro de 2002, listava a recolha de cerca de 800 peças, todas elas devidamente identificadas e fichadas, e apresentava os tópicos do que poderia vir a ser uma monografia da Luz, baseada no trabalho de recolha antropológica, abrangendo aspectos como a organização social e familiar, a agricultura e pastorícia, a pesca e as actividades fluviais, os tempos e as vivências e as actividades lúdicas e festas (Saraiva 2002).

Se bem que a recolha audiovisual tenha sofrido por não ter sido iniciada mais cedo, conseguiu-se no entanto um amplo registo das vivências na velha Luz. A equipa acompanhou a recolha etnográfica e museológica igualmente na segunda fase do projecto, o que permitiu enriquecer o acervo de imagens com os vários aspectos do processo efectivo de mudança das famílias e os primeiros

9 Por exemplo, em matéria de recolha audiovisual estava previsto, na primeira proposta, um levantamento exaustivo, com mais de 20 semanas de rodagem e visitas sistemáticas a todas as casas da Luz e aos espaços públicos, o levantamento em imagem dos ciclos agrícolas anuais, o seguimento integral da mudança dos habitantes para a nova aldeia e da posterior demolição da velha Luz e ainda filmagens na nova aldeia, de modo a registar a adaptação ao novo espaço. Com todos os constrangimentos a que fomos obrigados, no contrato finalmente assinado em Setembro de 2001 passou-se para oito semanas de filmagem e uma consequente diminuição da cobertura dos acontecimentos e das vivências familiares e sociais.

10 Como foi referido por um dos funcionários.

11 A equipa era constituída por um museólogo/etnólogo (Benjamim Pereira), uma historiadora (Sandra Monteiro), a produtora responsável pela recolha de material audiovisual (Laranja Azul) e eu própria, como responsável pelo projecto. 
dias nas novas moradas. Um ano após o início do trabalho de recolha, em Setembro de 2002, em plena efervescência do realojamento, tinham-se já passado vários momentos cruciais no processo, seguidos de perto por mim e por Benjamim Pereira e registados pelas câmaras da Laranja Azul - dos quais o encerramento das comportas da barragem em Fevereiro de 2002, a trasladação do cemitério em Julho e a festa anual em honra da Nossa Senhora da Luz foram os mais importantes no desenrolar dos acontecimentos.

A trasladação dos mortos foi um marco decisivo para a aceitação pelas famílias da sua mudança para a nova aldeia, já que os luzenses tinham decidido que "não abandonariam as suas alminhas" e que o realojamento dos mortos deveria anteceder o dos vivos. Durante 13 dias traumáticos de Julho reviveram-se as mortes dos entes queridos; mexer na comunidade dos mortos foi também tocar na memória sagrada da aldeia, e o processo despoletou uma catarse colectiva e um sentimento de solidariedade derivada do sentimento de união na dor. Com os seus mortos no novo espaço, só restava aos luzenses aceitarem com resignação que os vivos se mudassem também. A última festa em honra da N. ${ }^{a}$ Sr. ${ }^{a}$ da Luz na velha aldeia teve lugar, como habitualmente, no primeiro fim-de-semana de Setembro. Nos meses de Setembro e Outubro as dinâmicas das duas aldeias foram inteiramente pautadas pelo ritmo das mudanças (Saraiva 2003b; 2007).

A aldeia foi solenemente inaugurada pelo primeiro-ministro a 19 de Novembro de 2002, já com a maioria da população a viver lá. Nesse Outono e Inverno a chuva foi abundante, e nos primeiros meses de 2003 a altura das águas obrigava os resistentes a saírem da velha aldeia. Com a água já ao lado, a igreja matriz e a praça de touros foram demolidas em Fevereiro.

Com a população praticamente realojada, ${ }^{12}$ conseguiu-se virar um pouco a atenção da empresa para a questão do museu, então a ser construído (tal como a igreja matriz). A EDIA idealizou primeiro numa inauguração no Verão seguinte, quando se realizasse a primeira festa na nova aldeia, mas no início de Setembro tudo estava ainda muito atrasado. O museu foi finalmente inaugurado no aniversário da nova Luz, em Novembro de 2003.

\section{FAZER UM MUSEU EM TERRENOS CONTURBADOS - ETNOGRAFIA, TURISMO E RECOLHA DE LIXO}

No largo principal da velha aldeia havia uma casa que tinha sido disponibilizada pelos seus donos para usufruto colectivo; eram sobretudo os homens que ao fim do dia aí se juntavam para conviver e jogar cartas. Era também nesse espaço que se encontrava o que as pessoas denominavam, em 1998, quando comecei a trabalhar na Luz, "o museu" - um conjunto de miniaturas e cadeiras 
construídas por artistas e mestres locais, a que se juntavam peças ligadas à agricultura e pastorícia emprestadas por várias famílias, arrumadas em prateleiras, e alguns têxteis dispostos pelas paredes e em cima de uma cama de ferro.

A estes juntaram-se mais objectos emprestados por várias famílias e em Setembro de 2001 a Junta de Freguesia, com o concurso da EDIA e da Câmara Municipal de Mourão, inaugurou a Exposição Etnográfica da Luz, denominada "Memórias de uma Aldeia", que era acompanhada por uma pequena brochura com a listagem das peças, os nomes dos seus donos e um texto inicial que explicava o contexto e a razão da mesma: "A exposição etnográfica da Luz visa mostrar alguns fragmentos da vida desta aldeia, permitindo descobrir algumas alterações introduzidas ao longo do século XX (...) reconhecendo-se a necessidade de preservar a memória desta comunidade, iniciou-se um conjunto de iniciativas locais, que visam a informação, sensibilização e a participação da população na recolha etnográfica que está em curso. (...) Como a nova aldeia da Luz vai ter um museu, é de grande importância o envolvimento dos seus habitantes para a constituição do seu acervo, através da doação de diferentes objectos ou o simples registo informático dos mesmos nas suas casas. Esta exposição representa a aposta no trabalho comunitário que se irá desenvolver através do novo equipamento cultural colocado à disposição da população no museu da Nova Aldeia da Luz."

A exposição contava com cerca de 156 objectos, arrumados nas várias divisões da casa; a brochura agrupava-os segundo um critério misto de localização física e de função: corredor, cozinha, dispensa, actividades económicas, quarto e lavoura. Esta mostra esteve patente ao público durante cerca de um ano, até à festa de Setembro de 2002, quando se encerrou.

Para além de mostrar o empenho das pessoas em divulgar o seu património, o que sucedeu em torno desta exposição mostra o quanto uma recolha museológica está dependente de contextos e disputas políticas e sociais, e de como o antropólogo/museólogo é instrumentalizado nesses processos. A abertura da exposição reflectia também as disputas entre EDIA e Junta: a primeira, que estava a edificar um museu, e a segunda, que reivindicava a originalidade da ideia da construção de um museu para a Luz e queria um papel activo no processo. O outro ângulo da disputa era ainda mais complexo e tinha a ver com lutas entre as várias instâncias do poder local que, embora reflectindo diferenças partidárias, mostravam sobretudo as disputas existentes desde sempre entre a Luz e a sede de concelho, Mourão, compreensíveis em termos de afirmação de identidades locais que o processo de Alqueva veio reavivar. Estas contendas prendiam-se também com a indefinição da posse de estruturas públicas: a Junta queixava-se de que a EDIA nunca tinha definido quem (Junta ou Câmara) tinha o quê, quem iria ter a autoridade sobre os vários equipamentos públicos (entre os quais o museu), e sentia-se, de uma forma geral, desautorizada perante a Câmara, ao mesmo tempo que sentia que a municipalidade não defendia 
suficientemente os interesses da Luz em todo o processo de negociação com a EDIA e com o poder central. Em parte por causa destas disputas, e sabendo que a EDIA estava a erigir o museu, muitas pessoas retiraram, na Primavera de 2002, os seus pertences da colecção exposta, por não quererem que essas peças fossem "para o museu da EDIA".

A este contexto juntou-se outro, um movimento que se pode denominar como "neo-rural", e que surgiu em Portugal tardiamente, na esteira da revitalização de tradições na Europa (Boissevain 1992), tendo-se chegado a uma situação complexa e algo paralisante do que é património (Durand 2004: 111) - sintetizado muitas vezes pelas pessoas como algo que "é velho"; como diziam as pessoas da Luz, nós "andávamos à procura de coisas velhas para o museu". À aderência a padrões e estéticas urbanas e niveladoras, na medida em que anulam especificidades dos interiores das casas alentejanas e as tornam iguais a qualquer moradia dos arredores de Lisboa ou do Porto, contrapõe-se uma corrente em que se valorizam elementos ligados a uma vida de lavoura extinta ou em vias de extinção. Assim, as pessoas levaram da exposição da Junta o trilho e a charrua utilizada há 40 anos para as lavras (ou o trilho para as debulhas) para embelezar jardins e pátios; retiraram-se das doações ao museu alfaias agrícolas, como foices, ancinhos, pás de padejar, alforjes e mesmo polainas ou outras peças do vestuário utilizado pelos avós porque "o meu filho quere-os para pôr na parede". Exemplos claros de que o facto de se identificar e qualificar algo como "património" indica o quanto o seu significado cultural e o seu papel na vida social e económica mudaram (Durand 2006:19); nunca os avós dos luzenses se lembrariam de pendurar polainas na parede ou pôr um trilho no jardim.

Se é óbvio que todo o processo da Luz foi marcado por contradições e as pessoas declararam, de início, que queriam que a nova aldeia fosse "uma aldeia alentejana”, a verdade é que foi difícil fazê-las aceitar o projecto arquitectónico, e muitas lutas houve por causa da recusa das janelas de alumínio e de outros detalhes "modernos" que as pessoas queriam para as novas casas e que entravam em contradição com o plano de pormenor aprovado para a nova aldeia. Para além dos 25 projectos-tipo para as casas, fizeram-se 11 projectos específicos, que pretendiam reproduzir as casas com valor arquitectónico especial; dos 11 , apenas dois foram executados, já que as restantes famílias recusaram os seus, e apenas três casas aceitaram o chão de xisto que lhes era proposto como opção para o pavimento das novas moradias. ${ }^{13}$ Para a maioria das pessoas, chão de xisto e tecto de caniço eram sinónimos de um passado difícil, da dureza de vida dos seus pais e avós que haviam trabalhado nos montes e propriedades dos terratenentes da zona. Os alumínios e azulejos nas casas melhoradas da velha aldeia mostravam uma ascensão económica, muitas vezes fruto de anos de emigração. 


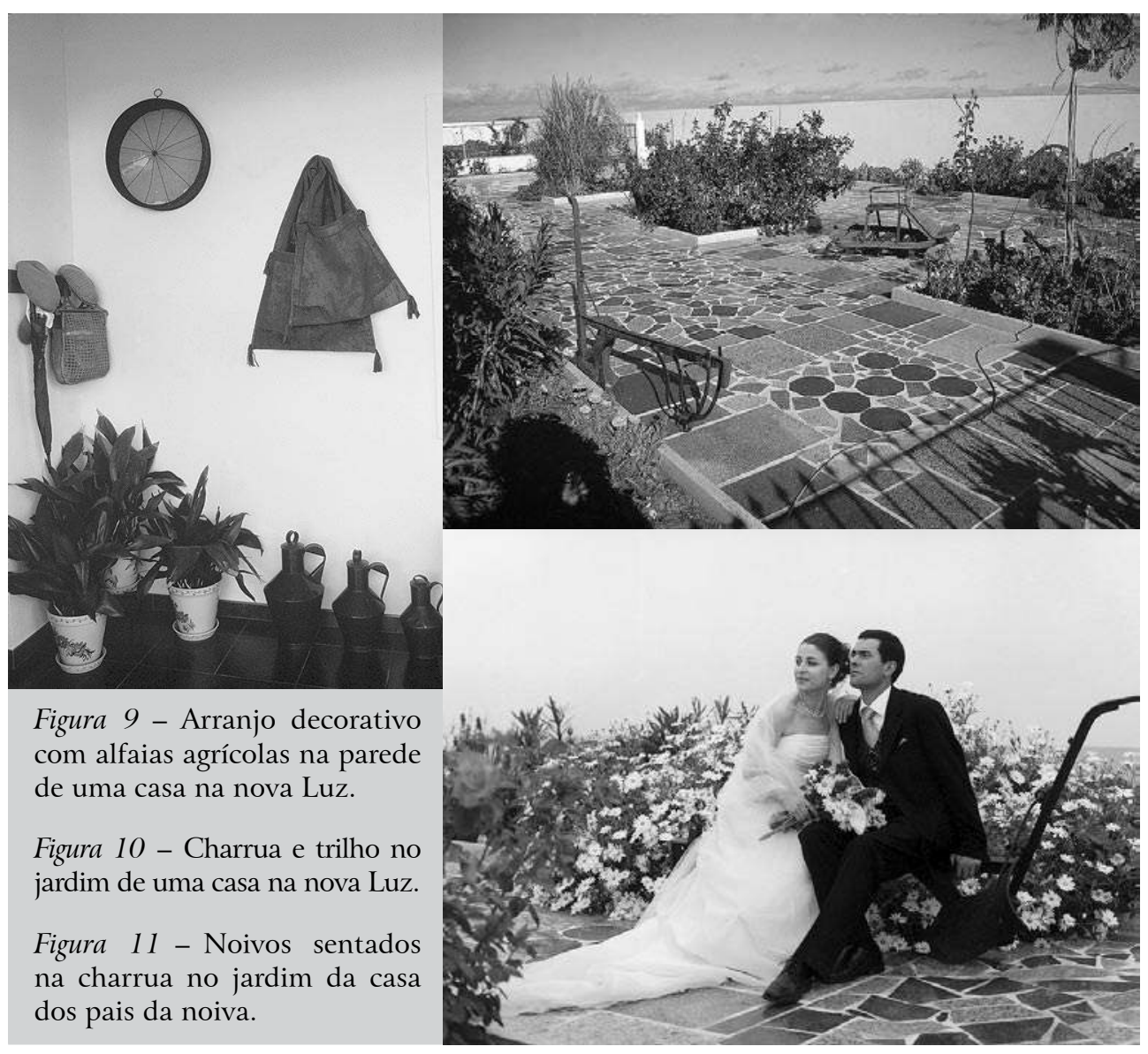

Com a perda irredutível dessas casas que mostravam a diferença, e o nivelamento a que o projecto arquitectónico da nova Luz obrigou, as pessoas engendraram novas formas de mostrar que nem todos eram iguais. A oscilação entre um passado (representado nos artefactos) de vida pobre e dura que se queria esquecer e a ideia de que, afinal, esse passado tinha coisas - nomeadamente essas mesmas materialidades - de que se deveriam orgulhar ("se os querem para o museu é porque são valiosos") impregnou todo o processo do refazer de identidades sociais. Do mesmo modo que, com a aldeia já habitada, as famílias mais abastadas começaram a introduzir modificações na frontaria das casas (sobretudo gradeamentos em ferro e alisares em azulejo ou mármore) como forma de afirmação social e de diferença, também os artefactos serviram o mesmo fim. Ter um trilho no jardim ou as polainas do avô na parede do pátio passou a distinguir os mais abastados, e que assim denotavam a sua superioridade não apenas económica, mas social e cultural. 
A tudo isto juntou-se a natureza humana e a vontade de ter algo que se desprezava, mas que de repente se torna apetecível porque alguém de fora mostra interesse por ela. Neste processo, Benjamim Pereira e eu éramos considerados peritos, "pessoas entendidas"; a "autoridade etnográfica" era aqui absoluta e se na maioria das alturas esse prestígio ajudou, nalgumas vezes, mercê desse traço, virou-se contra nós.

Numa da vezes em que saímos da velha aldeia vedada com um funcionário da EDIA, com um veículo de caixa aberta cheio de objectos resgatados dos quintais abandonados, que iriam ser armazenados junto com os demais, esperávamos na cancela que o segurança de serviço nos deixasse sair; atrás de nós parou a carrinha de um dos habitantes da Luz que ainda tinha os animais na velha aldeia, e por isso aí se deslocava diariamente. Após alguns minutos o homem saiu do carro e veio reclamar por termos connosco um pote de cal que ele dizia ser seu. Quando explicámos que ele o havia deixado abandonado no quintal da casa vazia e que portanto o tínhamos recolhido para o museu, tal como tinha sido previamente combinado, ele replicou que se nós queríamos o pote para o museu era porque ele era valioso, pelo que o queria de volta. De certa forma, este episódio corrobora a ideia do efeito relacional entre passado e presente na conceptualização do que é património, como Durand afirma: “(...) é o nosso olhar, ancorado no presente, que determina os valores que situamos no passado" (Durand 2004: 111). De algum modo, também nós, preocupados com os materiais que poderíamos angariar para o museu, jogámos com o dúbio e duplo sentido das "coisas velhas", e se, por um lado, nos empenhávamos em explicar que no museu não interessavam apenas "coisas velhas", por outro insistíamos na ideia de que o "lixo" que não queriam deveriam deixar nas casas abandonadas para que o recolhêssemos.

Apesar destes acontecimentos e das disputas várias entre as quais navegámos, a recolha de objectos foi feita, de casa em casa, até ao Verão de 2002. Com a mudança e o abandono das velhas casas no Outono, fomos sistematicamente solicitando a todas as famílias que não deitassem nada para o lixo, mas que deixassem o que não queriam nas casas, e nós verificaríamos posteriormente e veríamos o que se podia aproveitar para o museu.

Neste processo de selecção, trabalhámos em Dezembro numa aldeia deserta; com os funcionários da EDIA entrávamos nas casas esvaziadas e escolhíamos o que nos parecia susceptível de vir a ser acervo do museu. No meio de quintais cheios de entulho e anexos virados do avesso o Benjamim descobria verdadeiras "obras de arte", peças interessantes que, apesar de material e simbolicamente esfiapadas, contavam no entanto muito sobre o que havia sido a vida daquela aldeia e daquelas gentes - potes de barro, cortiços, utensílios agrícolas e de uso quotidiano. Combinámos que deixaríamos o "montinho" de haveres seleccionados em cada casa, num canto, e que o funcionário 
do GRAL $^{14}$ passaria posteriormente com a carrinha para os levar para o local onde se estavam a guardar.

No período dos feriados do Natal e Ano Novo a chuva parou e o sol convidou a passeios. A velha Luz, já vedada mas ainda não interditada à entrada, foi invadida por turistas; quando voltámos ao trabalho, passados alguns dias, todos os objectos que havíamos seleccionado tinham desaparecido. Os turistas tinham vindo e levado consigo potes partidos, colmeias de cortiça, pedaços do xisto que restava das vigas das lareiras... O que aconteceu foi um fenómeno em escala alargada do que as pessoas da Luz se queixavam sobretudo nos últimos meses de permanência na velha aldeia: que "os de fora vinham, espiolhavam, roubavam coisas dos jardins e até plantas".

Um dos episódios que me foi relatado é sintomático da apetência das pessoas por possuírem um pedaço fetiche de aldeia "heroína nacional" que iria desaparecer sob as águas da albufeira. Uma das minhas vizinhas da parte antiga da aldeia contou-me que tinha apanhado, nos meses de Verão, um casal a levar plantas e uns potes e que, perante o seu protesto, afirmaram: "Desculpe, mas é que a gente quer ter uma recordação daqui, da vossa aldeia que vai desaparecer". Pessoas sem qualquer ligação prévia à Luz, vindas de Trás-os-Montes ou do Algarve em camionetas de excursão, de repente comentavam, de lágrimas nos olhos, no largo 25 de Abril, como o fado da aldeia era triste e como se sentiam infelizes pelas pessoas da Luz, "coitadinhas".

Para além de considerações sobre a gestão dos processos emocionais individuais e sociais, ${ }^{15}$ e da quantidade de catarses colectivas por que a Luz passou, o fenómeno de musealização perante a iminência do desaparecimento de algo é interessante, apesar de sabermos de antemão que a maioria dos processos de musealização começa por aí. Se a equipa de Jorge Dias - Jorge e Margot Dias, Fernando Galhano, Ernesto Veiga de Oliveira e Benjamim Pereira - decidiu, nos anos 60, dirigir os seus trabalhos de pesquisa em Portugal para a cultura material, foi justamente por sentir a premência da necessidade de uma intervenção num país em rápida mutação, em que dentro de poucos anos não restariam testemunhos do que havia sido uma cultura material rica e diversificada, em muitos casos única na Europa. ${ }^{16}$ No caso da Luz, foi a urgência decorrente do seu iminente desaparecimento que transformou todo e qualquer português visitante da aldeia num exímio e consciencioso museólogo, ávido de se apropriar do bem antes que ele desapareça.

14 O GRAL era o Gabinete de Realojamento da Aldeia da Luz, o gabinete da EDIA instalado na velha aldeia; com a mudanca o GRAL foi tambem reinstaldo na nova Luz.

15 Ver, a este respeito Lutz e White (1986); Lutz (1988); Lutz e Abu-Lughod (1990).

16 Por exemplo, em termos de sistemas de elevagem de água de rega, como Ernesto Veiga de Oliveira (Olivera e Galhano 1992) salientou. 


\section{PESSOAS E PROCESSOS DE MUSEALIZAÇÃO}

De certo modo, a velha Luz passou ela própria por um processo de musealização; condenada a desaparecer sob as águas de Alqueva, em pouco tempo uma aldeia desconhecida passou para as manchetes das notícias, e as pessoas, autóctones e forasteiras, passaram a valorizar o que antes não tinha qualquer valor. Se para definir a sua identidade uma comunidade não pode cessar de produzir a diferença (Chappaz-Wirthner in Bromberger 2003: 15), a Luz passou por um processo extremo de exagero de produção dessa diferença. De aldeia perdida no final de uma estrada sem saída, numa zona esquecida do Sul, ela passou em pouco tempo a ser o pólo das atracções nacionais. A afluência das pessoas de fora começou com os primeiros estudos sobre a barragem e com o início da construção da nova aldeia. Vieram arquitectos e engenheiros, cineastas, fotógrafos, historiadores, sociólogos e antropólogos. Além destes, a Luz habituou-se a dois outros grupos alógenos desconhecidos até então para a maioria da população: os imigrantes estrangeiros que vieram trabalhar para as obras e os turistas. Com os primeiros os luzenses estabeleceram algumas relações, conscientes de que a aldeia tinha agora "pessoas vindas dos quatro cantos do mundo", numa atitude compreensiva, já que, como muitos diziam, numa clara alusão à própria emigração, "nós também sabemos o que é lutar pela vida e trabalhar fora da nossa terra para ganhar algum e melhorar a vidinha da nossa família".

Os turistas invadiram a Luz sobretudo no último ano antes da mudança da aldeia, quando Alqueva era objecto de notícias e escândalos diários nos jornais, rádios e televisões nacionais. ${ }^{17}$ Durante os fins-de-semana do Verão de 2002 chegavam a entrar diariamente 30 autocarros e centenas de automóveis que provocavam engarrafamentos a ponto de se ter requerido a presença da GNR para restringir a circulação e impor sentidos únicos. No largo 25 de Abril, nas tardes tórridas dos domingos de Agosto, havia muitas vezes mais turistas que autóctones (Saraiva 2003a: 42). Os luzenses viam o desfile de pessoas que para eles olhavam com um misto de orgulho da sua afirmação da identidade local e de repúdio por um devassar de espaços e privacidades que sentiam como sua pertença. $\mathrm{O}$ orgulho estava aliado à constatação do interesse que os demais manifestavam pela sua aldeia antes desconhecida, pela notoriedade que o seu sacrifício lhes trouxe a nível nacional; mas essa atracção pela fama envolvia também um outro lado, e uma certa saturação que foi aumentando à medida que os anos passavam, as obras avançavam e o número de visitantes crescia.

17 Em torno da questão de Alqueva levantaram-se muitas questões par além do problema da Luz, sobretudo do foro ambiental, mas também económico e patrimonial. Ver entre outros, Caldas (1998; 2003); Daveau (1977); Drain (1996; 1998; 2002; 2003); Lanca (2003); Medeiros (1998); Saraiva (2005); Silva (1999; 2000); Wateau $(1999 ; 2002)$ e os periódicos nacionais entre 1998 e 2003. 
De heróis, os luzenses passaram a sentir-se duplamente vítimas: pelo processo traumatizante por que passavam, mas também porque se sentiam "olhados como se fossemos peças de museu ou animais do jardim zoológico”.

Este efeito de se sentirem eles próprios, ironicamente, como objectos de um museu vivo, tomou novas facetas quando, com a chegada de Janeiro de 2003 e a maioria das famílias instaladas e a viverem na nova aldeia, a velha Luz foi vedada, para se dar início ao processo de desmantelamento e posterior demolição. Os turistas, que continuaram a ir ao castelo da Lousa até à altura em que este foi coberto de sacos de areia e deixou de poder ser visitado, tinham a entrada interditada na aldeia; as excursões passaram a parar na estrada, perto da entrada fechada do povoamento e, junto à vedação que circundava todo o perímetro urbano, olhavam, comentavam e tiravam fotografias.

Mas o processo de musealização da Luz teve igualmente a ver com a acção dos próprios autóctones. Foi sempre dito que a velha aldeia, uma vez vazia, seria inteiramente demolida. Esta decisão tinha dois objectivos: um do foro ambientalista, como medida de preservação da qualidade da água; e um segundo, de carácter psicológico, para evitar às pessoas o confronto com as ruínas do antigo núcleo em anos de seca e consequente abaixamento do nível das águas. No quadro de ódio e contestação perante a EDIA, e com o velho burgo já completamente vedado e prestes a iniciar-se a demolição, a empresa teve a ideia de permitir aos próprios que iniciassem o processo de desmantelamento

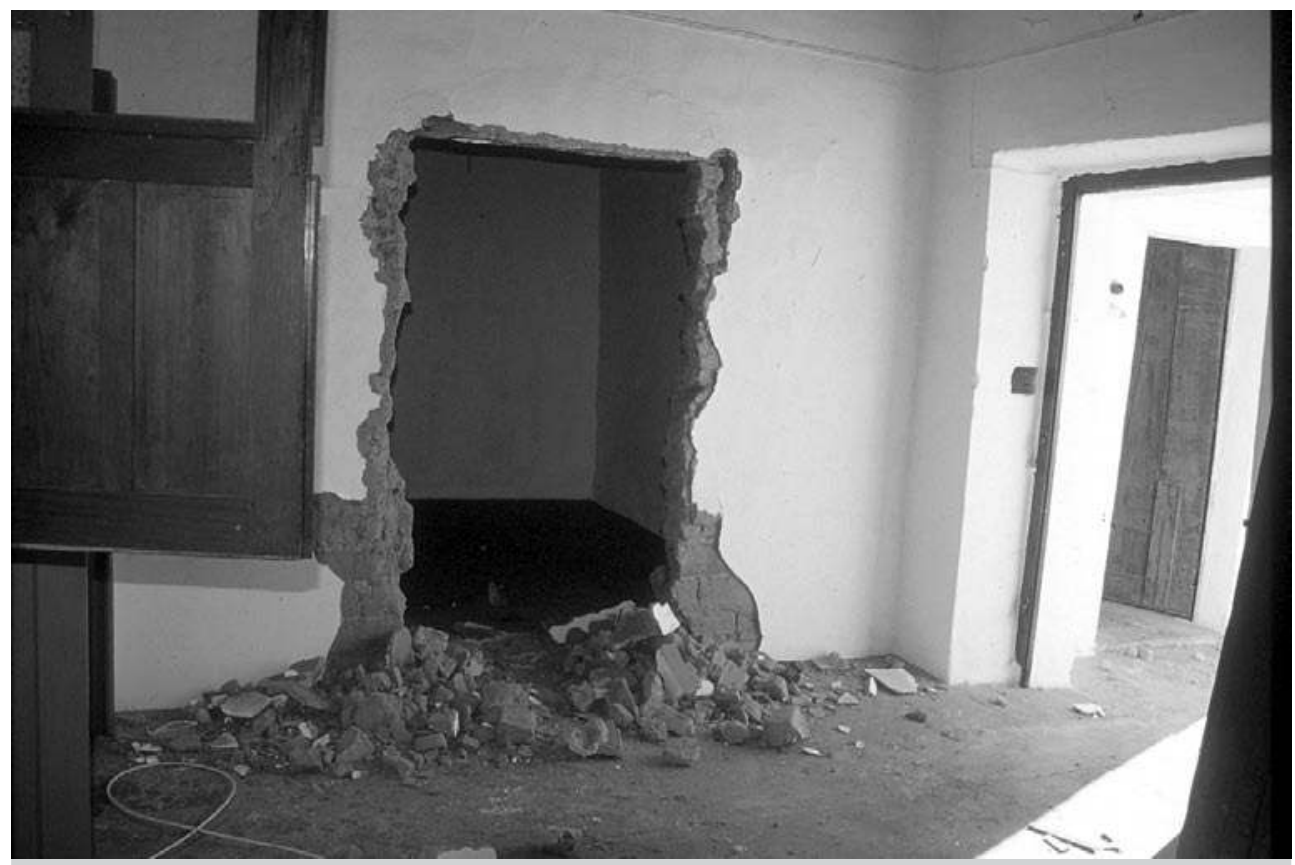

Figura 12 - Casa vazia e já semidestruída na velha Luz. 
das suas casas, retirando das casas vazias os elementos estruturais que desejassem. Apesar desse movimento se ter iniciado com a própria mudança das casas, o conhecimento daquela resolução imprimiu uma dinâmica própria a estas acções. Ao longo dos anos tinha-se afirmado, sobretudo em momentos de mais intenso confronto com a empresa, que se preferia destruir os haveres a abandoná-los para o inimigo, a EDIA. Esta asserção estava patente em frases como: "Tudo o que eu puder tirar eu tiro. Eu não fico com elas, mas 'eles' também não hão-de ficar! Aqui não fica nada para eles!”.

De posse de uma credencial passada pela EDIA, os luzenses retiraram tudo o que haveria para retirar: portas, janelas, vigas, telhas. De um ponto de vista estratégico, a resolução da EDIA revelou-se um sucesso: não poderia mais ser dito que a empresa ficava com algo que pertencia às pessoas, já que os libertava para levarem tudo o que desejassem. Desta forma, foram os próprios luzenses os primeiros agentes de demolição da sua velha aldeia, o que, de um prisma psicológico, foi extremamente pedagógico e reconfortante: não se "deixava nada para a EDIA" e eram as pessoas, pelas suas próprias mãos, que iniciavam a destruição das suas antigas moradas (Saraiva 2005).

O mesmo fenómeno que se passou com os objectos passou-se com os elementos da casa, mas com uma lógica inversa: enquanto que com os objectos se passou da atitude de atirar as coisas velhas fora para uma valorização das mesmas coisas, que de repente passavam a "coisas boas", património, já que eram valorizadas por outrem (nomeadamente nós, "as gentes do museu”), em relação aos elementos estruturais da casa, importava sobretudo retirar portas e janelas de alumínio, azulejos das paredes ou ladrilhos dos pavimentos e outras "coisas modernas e que custaram muito dinheiro", para serem colocadas em anexos a construir nos pátios traseiros da nova casa. Por outro lado, havia também um agente de definição do que era "património" exterior: estava definido a priori no plano de desmantelamento que todos os "elementos patrimoniais" seriam preservados e reciclados. O processo de desmantelamento foi por isso lento e trabalhoso. Foram retiradas e separadas as telhas, os elementos estruturais "patrimoniais" a devolver às pessoas (como as vigas de xisto das lareiras, as lajes de xisto que constituíam bancos nas cozinhas, despensas ou pátios), as partes em madeira (caixilhos de janelas, portas, portadas, etc.) de modo a que tudo fosse reciclado; só depois as grandes máquinas de demolição deitariam abaixo as paredes. Iniciada em Fevereiro de 2003, só meses depois, em Setembro desse ano, a demolição pôde ser completada. De certo modo, os luzenses inventaram, não uma tradição (Hobsbawm e Ranger 1984), mas uma conceptualização de património enquanto um continuиm que adquire validade perante a inevitabilidade da destruição do mesmo. Se instâncias exteriores determinaram que uma viga de chaminé em xisto, com a data de 1879 era património a não descurar, num clima social e psicologicamente conturbado, não teriam as pessoas direito a declarar como património um caixilho de alumínio? 
E quando, daqui a 50 anos, se fizer no museu da Luz uma exposição sobre o processo de mudança, não terá esse caixilho de alumínio um lugar de destaque, símbolo das vicissitudes por que uma aldeia passou?

A destruição da aldeia foi, assim, um processo paulatino, observado e participado, um acto público em que as pessoas foram intervenientes activas. À medida que a Luz era destruída, ia-se erguendo na nova aldeia o novo museu.

\section{INSTITUIÇÕES E PESSOAS: RELATOS NO SINGULAR}

É sobretudo no palco de situações controversas que, tal como Christian Bromberger (2004: 17) salienta, "pessoas singulares", intermediários entre as pessoas, o seu mundo cultural e as administrações e burocracias variadas assumem uma função preponderante, mobilizando sinergias e actores e assumindo amiúde o papel de agentes do desenvolvimento local. Alqueva não só alterou o mapa geográfico da região mas despoletou conflitos aos vários níveis; envolvendo estruturas públicas ao nível europeu (União Europeia), central (os ministérios de que a EDIA foi dependendo), regional (Comissão de Coordenação da Região do Alentejo) e local (Câmara Municipal de Mourão e Junta de Freguesia), além dos muitos outros organismos chamados a contribuir, dar pareceres ou decidir sobre assuntos, nos mais diversos quadrantes, do ambiental ao económico, tudo neste processo foi controverso e difícil.

Durante os meses de Janeiro a Março voltámos repetidas vezes à velha Luz para continuar a "descoberta" de objectos deixados pelas pessoas. Era um espectáculo estranho e perturbante, o de observar a fragilidade de estruturas anteriormente vestidas por uma cultura de que a retirada de elementos materiais tinha também retirado a vida. A harmonia dada às casas por um sentido estético qualificado que os seus moradores lhes imprimiam desaparecera, e o que restara eram paredes sem tectos, e restos semidestruídos. Era flagrante a oposição entre estas casas abandonadas e parcialmente destruídas e os mesmos edifícios, meses antes, quando, à altura da mudança dos seus ocupantes, tinham sido escrupulosamente varridas e limpas (Saraiva 2005: 270).

As disputas entre a EDIA e outras instâncias continuaram; as relações com a Junta de Freguesia, representante dos anseios da população, agudizaram-se; no Verão de 2003 não se terminava a demolição porque a Junta não permitia a destruição de dois edifícios que lhe pertenciam e que eram os únicos que restavam da velha aldeia, sozinhos no meio de um campo poeirento e nivelado, em que todo o entulho havia já sido removido.

Com os esforços centrados no museu que a EDIA queria inaugurar em Novembro, passou a ser esse o pólo das discórdias. O Monte dos Pássaros era necessário enquanto espaço para se proceder à limpeza e restauro das peças que iriam figurar nas exposições inaugurais. Mas a Junta tinha atulhado esse 
espaço de mobiliário retirado da antiga Junta, e não cedia em retirá-lo de lá a não ser que a EDIA aceitasse algumas das reivindicações, nomeadamente em relação a espaços e edifícios aos quais a Junta achava ter direito. Entre reuniões com funcionários e administração da EDIA e com o presidente da Junta, conseguimos alguns contentores para se colocarem as peças, e pessoas para fazerem o restauro. Uma das dificuldades era convencer as pessoas que o museu não era "da EDIA", mas sim seu, e tentar atraí-las para uma intervenção activa no que queríamos fosse sentido como um espaço colectivo dos luzenses, tal como tinha sido pensado desde o início.

No dia da inauguração vieram os políticos, as autoridades locais e regionais, os jornalistas... mas também vieram as gentes da Luz, e o grupo coral local cantou nas salas do museu. Com a quantidade de rituais novos por que a Luz passou, numa sucessão infindável de despedidas de velhos espaços e de inaugurações de novos, esta celebração marcou o fim de um ano inicial de vivências no novo espaço e passou a ser uma das datas importantes e comemoradas anualmente. ${ }^{18} \mathrm{O}$ pretendido renascer da Luz passou também por novas formas de encarar a vida, tanto para os mais velhos, como sobretudo para os mais novos - os que passaram a ter penduradas nas paredes as polainas dos avós.

\section{MUSEU DA LUZ: PRESENTE E FUTURO}

Se um dos aspectos mais interessantes do museu se prende com a aparente contradição da interioridade do seu aspecto exterior e a sua elaboração arquitectónica, assente numa relação muito forte entre o edifício e o meio natural circundante, esta sua condição pode com certeza ser olhada como complementar à função que o museu se propôs e que se espera consiga sempre cumprir, enquanto pólo dinamizador de energias e de perspectivas futuras para a Luz e para o mundo. Não se quer um museu virado para o trauma do passado recente, ${ }^{19}$ mas sim um equipamento que dê a conhecer uma zona marginalizada do país aos de fora, mas que sobretudo seja um lugar onde os luzenses se sintam em casa.

Os Luzenses vão ao museu, mas não tanto como desejaríamos. Quando chega alguma visita - familiares ou amigos de fora - é levada ao museu, para ver as exposições e o filme, onde cada um aparece por escassos segundos conferidores imortalidade. $\mathrm{O}$ orgulho de muitos que doaram peças e as vêem expostas é também um modo de mostrar formas de vida de um passado recente

18 A proposito de comemorações e memórias performativas da história, ver Young (1993).

19 Como o caso dos museus que retratam outras memórias traumáticas como o holocausto judaico na Alemanha ou as referidas memórias performativas da história, como o Yom Hashoah em Israel (Young 1993). 
que as pessoas entretanto, e gracas também ao processo por que passaram, passaram a valorizar.

Os turistas afluem; apesar da grande torrente dos anos da mudança ter desaparecido da aldeia, o Museu da Luz recebeu no primeiro semestre de 2007 cerca de 1400 visitantes por mês, um número muito superior ao do Museu Nacional de Etnologia, em Lisboa. Ganhou vários prémios de arquitectura ${ }^{20}$ e uma menção honrosa da APOM (Associação Portuguesa de Museologia) na categoria "Melhor Museu do País". O museu tem uma linha editorial, fazem-se programas completos e actividades com escolas, exposições de fotografia, lançamentos de livros; em cada dois meses é seleccionado um objecto do acervo que é apresentado (na mesa da Sala da Memória) através dos depoimentos dos seus doadores, dando assim "voz e vida" às peças.

Ultrapassando o âmbito local, o museu abre-se a perspectivas de futuro que queremos ver contempladas pelas instâncias que o tutelam, que esperemos não se dediquem apenas às turbinas e aos canais de rega e não abandonem um pólo potencialmente dinâmico e vivo como este. Tal como Maria João George referia, por ocasião da sua inauguração: "A evolução do conhecimento em torno da memória da Luz conduziu ao dimensionamento do projecto numa escala completamente diversa daquela que era ab initio imaginada pelos seus habitantes, não só pela amplitude do investimento global como pelo carácter representativo que encerra e ainda pelo que promete vir a ser. O projecto museológico assume agora uma perspectiva cujo impacte transcende claramente o âmbito de um museu local e o coloca ao nível de uma intervenção de âmbito regional" (George 2003: 9).

20 1. P Prémio Europeu de Arquitectura Luigi Cosenza '04; Prémio MENHIR, IV edição (Publicações Menhir, S.L. de Bilbao, Vizcaya); nomeação entre os 10 primeiros no Prémio SECIL 2004; o conjunto da obra Museu+Igreja+Cemitério entre os cinco melhores do Prémio Internacional de Arquitectura de Pedra 2005 (Verona, Itália); o conjunto na categoria de Conservação do Património Arquitectónico, Prémio Europa Nostra 2006. O projecto do Museu da Luz esteve também representado na Trienal de Arquitectura de Lisboa, no núcleo Eurovison, patente no Pavilhão de Portugal da Expo entre Maio e Julho de 2007. 


\section{BIBLIOGRAFIA}

BOISSEVAIN, Jeremy, 1992, Revitalizing European Rituals. Londres, Routledge.

BROMBERGER, Christian, e Denis Chevallier, 2004, "De la métamorphose de la châtaigne à la renaissance du Carnaval. Relances de traditions dans l'Europe contemporaine”, em C. Bromberger, et al. (dir.), De la Châtaigne au Carnaval. Relances de Traditions dans l'Europe Contemporaine. Die, Éditions A Die.

CALDAS, João Castro, 2003, "Problemas colocados pelos recursos hídricos portugueses provenientes de Espanha", in Michel Drain (ed.), Politiques de l'Eau en Milieu Méditerranéen. Le Cas de la Péninsule Ibérique. Madrid, Collection de la Casa de Velásquez.

__, 1998, "Portugal-Espagne, la question de l'eau”, Régulation de l'Eau en Millieu Méditerranéen. Risques et Tensions, Territoires en Mutation 3, pp. 233-237. Montpellier, Université Paul Valéry Montpellier III.

DAVEAU, Suzanne, 1977, "Bases geográficas para o problema da barragem do Alqueva, achegas para a sua representação", Finisterra, 24 (XII).

DRAIN, Michel, 2003, "Les eaux partagées avec le Portugal”, em Politiques de l'Eau en Millieu Méditerranéen. Le Cas de la Péninsule Ibérique. Madrid, Casa de Velásquez, Universidad de Alicante.

— 2002, "Les identités territoriales du Portugal. Le poids des imaginaires", Lusotopie 2002/2, pp. 159-163.

__, 1998, "Planificación de las aguas peninsulares a escala europea", Actas do Congreso Ibérico Sobre Géstion y Panificación de Aguas, Zaragoza, pp. 847-855.

— Mediterranéenne, Espace Rural 36, pp. 115-129. Montpellier, Université Paul Valéry Montpellier III.

DURAND, Jean-Yves, (org.), 2006, Os “Lenços de Namorados". Frentes e Versos de um Produto Artesanal no Tempo da sua Certificação, Comissão de Coordenação e Desenvolvimento da Região Norte (CCDRN) e Câmara Municipal de Vila Verde.

— 2004 , "O antigo e o novo", em J.-Y. Durand (coord.), Vila Verde: uma Etnografia no Presente. Vila Verde, Câmara Municipal de Vila Verde.

EDIA 1995, Concurso Público Internacional n. ${ }^{\circ} 3 / 95$ no âmbito da União Europeia para a elaboração do projecto de Plano e Pormenor da Nova Aldeia da Luz, Setembro 1995, Beja, EDIA.

FERRO, Joaquim Dimas, 2004, Museu da Luz. Contributos para a Sua Identidade Cultural, dissertação de mestrado, Departamento de História, Universidade de Évora.

FIGUeIRA, Francisco, 1997a, Projecto do Plano de Pormenor da Nova Aldeia da Luz, Fevereiro de 1997.

—_, 1997b, Anteprojecto das Habitações da Nova Aldeia da Luz, Dezembro de 1997.

GEORGE, Maria João, 2003, “O Museu da Luz”, Museu da Luz. Catálogo. Luz, EDIA.

HALBWACHS, Maurice, 1968, La Mémoire Collective. Paris, PUF.

HOBSBAWM, Eric, e Terence Ranger, 1984, The Invention of Tradition. Cambridge, Cambridge University Press.

LANÇA, Maria João (coord.), 2003, No Tempo dos Moinhos do Guadiana e Outros Tempos. Beja, EDIA.

LATZ, A., 1979, Il Était une Fois un Village. Étude Psychosociologique des Conséquences de la Transformation d'un Environnement: Étude Réalisée sur le Village de Salles-en-Provence. Bruxelas, Edition de l'Université de Bruxelle. 
LUTZ, Catherine, e Geoffrey White, 1986, “The anthropology of emotions”, Annual Review of Anthropology, 15, pp. 405-436.

LUTZ, Catherine, 1988, Unnatural Emotions. Everyday Sentiments on a Micronesian Atoll and their Challenge to Western Theory. Chicago, The University of Chicago Press.

LUTZ, Catherine, e Lila Abu-Lughod, 1990, Language and the Politics of Emotion. Cambridge, Cambridge University Press.

MOURÃO, Catarina, e Catarina Alves Costa, "Imagens e sons para o Museu da Luz", Museu da Luz, Catálogo. Luz, EDIA.

NOVAES, Gladys, 1973, "A retirada de Vilarinho das Furnas”, Geographica 33, pp. 53-71.

OLIVEIRA, Ernesto Veiga de, e Fernando Galhano, 1992, "Persistência e evolução da habitação tradicional", Arquitectura Tradicional Portuguesa. Lisboa, Dom Quixote.

PACHECO, Pedro, Marie Clément, e Frédéric Bonnet, 1998, Proposta para a Elaboração de Projecto de Execução da Unidaded de Projecto 4, manuscrito, Lisboa.

PACHECO, Pedro, e Marie Clément, 2006, Museu da Luz. Matéria e Memória, manuscrito. Lisboa.

—, 2004, Núcleo Etnográfico do Monte dos Pássaros. Estudo Prévio, manuscrito. Lisboa.

—_, 2003, "Aldeia da Luz/Aldeias duplas", Museu da Luz. Catálogo. Luz, EDIA.

PEREIRA, Benjamim, 2005, Testemunhos da Arquitectura Tradicional. Monte dos Pássaros, Futuro Núcleo do Museu da Luz, Textos Exposição. Luz, Museu da Luz/EDIA.

—, 2003, "Museu da Luz", Museu da Luz. Catálogo. Luz, Museu da Luz/EDIA.REYMOND, José, 1992, Tignes, Mon Village Englouti. Paris, Payot.

SARAIVA, Clara, 2007 "Mudança e água no Sul de Portugal: a barragem de Alqueva e a aldeia da Luz", Ruris, Revista do Centro de Estudos Rurais/Universidade Estadual de Campinas, Instituto de Filosofia e Ciências Humanas da Unicamp (CERES/IFCH/Unicamp), vol. 1, n. ${ }^{\circ} 1$ (2007), Brasil.

—, 2005, Luz e Água. Etnografia de um Processo de Mudança. Beja, EDIA.

__, 2003a, "Uma aldeia de Luz e água”, Museu da Luz, Catálogo. Luz, EDIA.

— - 2003b, "Aldeia da Luz: entre dois solstícios, a etnografia das suas continuidades e mudanças”, Etnográfica, VII (1), ISCTE/CEAS.

— , 2003c, Museu da Luz, Catálogo (coordenação em colaboração com Benjamim Pereira e Maria João George). Luz, EDIA.

— 2002, Relatório da Primeira Fase do Projecto de Assistência Técnica para a Constituição do Acervo Museológico da Luz, manuscrito. Lisboa.

— do Museu da Nova Aldeia da Luz", Projecto de Assistência Técnica para o Museu da Luz.

SERRÃO, Adérito, 1999, "Alqueva, uma alavanca de progresso para o Alentejo no século XXI", Alqueva, Centro do Mundo? Actas da 8. ${ }^{a}$ Edição dos Encontros de Monsaraz. Monsaraz, Associação de Defesa dos Interesses de Monsaraz (ADIM).

SILVA, António Carlos, (coord.), 2000, Das Pedras do Xerez às Novas Terras da Luz. Beja, EDIA. —_, 1999, Salvamento Arqueológico no Guadiana. Do Inventário Patrimonial à Minimização dos Impactes. Beja, EDIA.

SILVA, Antunes da, 1982, Alqueva, a Grande Barragem. Lisboa, Livros Horizonte.

VAlCELl, Anne Sophie, 2002, Les Salles-sur-Verdon. Du Passé à l'Avenir, memoire de DEA. Aix-en-Provence, Université de Provence, Aix-Marseille 1.

WATEAU, Fabienne, 2002, "Du Portugal à l'Europe. Effets d'échelles, de Melgaço à Alqueva", Lusotopie, 2, pp. 165-176. 
WATEAU, Fabienne, 1999, "Barrages, identités et frontiéres. Des barrages sur rivières frontalières (Sela et Alqueva)", Globalización, Fronteras Culturales y Políticas, y Ciudadanía. Actas del VIII Congreso de Antropologia, Santiago de Compostella, pp. 229-244.

YOUNG, James E., 1993, The Texture of Memory: Holocaust Memorials and Meaning. New Haven e London, Yale University Press.

\section{FILMOGRAFIA}

LUZ, Fátima, 2003, A Luz Vai-se Apagar. Portugal, Produção Keyframe/Multicanal. MATOS SILVA, Fernando, 2001, Luz Submersa. Portugal.

MOUrÃo, Catarina, 2005, A Minha Aldeia Já Não Mora Aqui. Portugal, Produção Laranja Azul.

RODRIGUeZ, Rámon, 2003, Aldeia da Luz, uma Terra Submersa Pelas Águas. Produção Tragaluz, SL.

SARAIVA, Eduardo, e Muriel Jacquerod, 2003, Entre Duas Terras. Les Films de la Cigogne.

Créditos fotográficos: Benjamim Pereira (figuras 1, 9, 10 e 12); atelier Pedro Pacheco e Marie Clément (figuras 2, 3, 4, 6 e 7); Paulo Nuno Silva (figuras 5 e 8); e cedência de Rosa Matilde Correia (figura 11).

A museum under water: the case of the village of Luz - Clara Saraiva - Instituto de Investigação Científica Tropical e Universidade Nova de Lisboa • clarasaraiva@fcsh.unl.pt

The Museum of Luz opened in 2003, as part of the plan for the reallocation of the village of Luz, submerged due to the construction of the Alqueva dam, in southern Portugal, and respecting the population's desire to have a museum in the new village. The reallocation process included the trasladation of the cemetery and of the old $15^{\text {th }}$ century church, both important simbolic buildings, relating to the foundation of the community and with which the museum established a strong relatiom. This text intends to explain what this museum is and some of the problems that we faced during the complex process of the reallocation of the village and of the creation of this equipment in the new Luz.

KEYWORDS: Alqueva dam, southern Portugal, reallocation process, Museum of Luz, ethnography, musealization. 